\title{
Storage of LWR Spent Fuel in Air
}

Volume 1-Design and Operation of a Spent Fuel Oxidation Test Facility

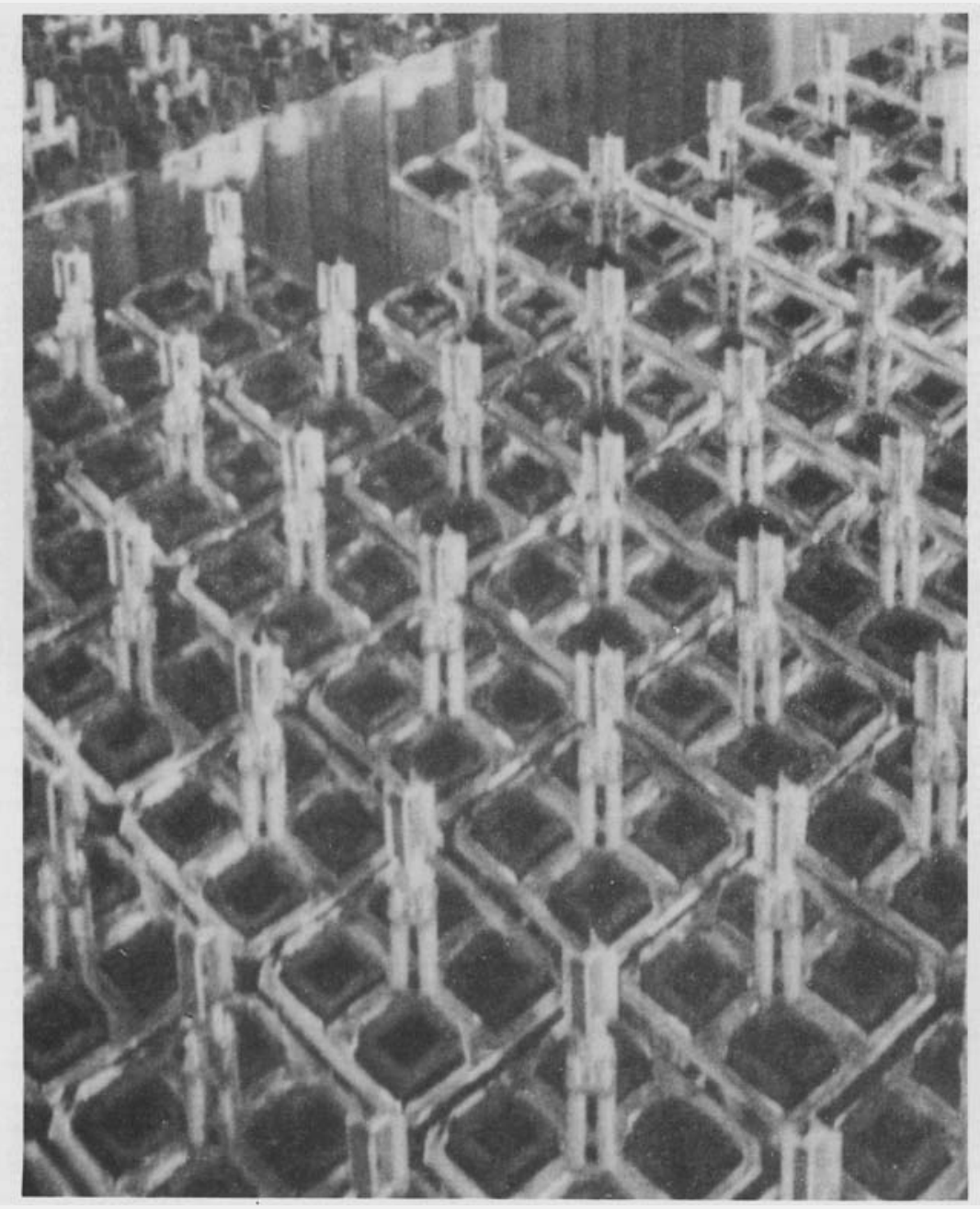

December 1988

Prepared for the U.S. Department of Energy under Contract DE-AC06-76RLO 1830

Pacific Northwest Laboratory Operated for the U.S. Department of Energy by Battelle Memorial Institute 


\section{DISCLAIMER}

This report was prepared as an account of work sponsored by an agency of the United States Government. Neither the United States Government nor any agency thereof, nor Battelle Memorial Institute, nor any or their employees, makes any warranty, expressed or implied, or assumes any legal liability or responsibility for the accuracy, coimpleteness, or usefulness of any information, apparatus, product, or process disclosed, or represents that its use would not infringe privately owned rights. Reference herein to any specific commercial product, process, or service by trade name, trademark, manufacturer, or otherwise does not necessarily constitute or imply its endorsement, recommendation, or favoring by the United States Government or any agency thereof, or Battelle Memorial Institute. The views and opinions of authors expressed herein do not necessarily state or reflect those of the United States Government or any agency thereof.

\section{PACIFIC NORTHWEST LABORATORY operated by \\ BATTELLE MEMORIAL INSTITUTE for the \\ UNITED STATES DEPARTMENT OF ENERGY under Contract DE-AC06-76RLO 1830}

Printed in the United States of America
Available from
National Technical Information Service
United States Department of Commerce
5285 Port Royal Road
Springfield, Virginia 22161
NTIS Price Codes
Microfiche A01
Printed Copy
Pages
$001-025$
$026-050$
$051-075$


PNL-6640 Vol. 1

UC- -85

STORAGE OF LWR SPENT FUEL IN AIR

Volume 1 - Design and Operation of a Spent Fuel Oxidation Test Facility

C. K. Thornhill

T. K. Campbell

R. E. Thornhill

December 1988

Prepared for the U.S. Department of Energy under Contract DE-AC06-76RLO 1830

Pacific Northwest Laboratory Richland, Washington 99352 


\section{PREFACE}

This report is one of four volumes in a series entitled Storage of Spent Euel in Air, being prepared for the U.S. Department of Energy, Office of Civilian Radioactive Waste Management, through the Commercial Spent Fuel Management Division of the Richland Operations Office on the storage of spent fuel in air. The project is managed by the Commercial Spent Fuel Management Program office at the Pacific Northwest Laboratory. Subjects covered in each volume in the series are as follows:

- Volume I--Design and Operation of an Experimental Facility for Conducting Spent Fuel Oxidation Tests.

- Volume II--Results from Spent Fuel 0xidation Tests in Air.

- Volume III--Characterization of Oxidized LWR Spent Fuel.

- Volume IV--Temperature Limits for Storing LWR Spent Fuel in Air. 


\section{$\underline{\text { SUMMARY }}$}

This report describes the design and operation and technical accomplishments of a spent-fuel oxidation test facility at the Pacific Northwest Laboratory. The objective of the experiments conducted in this facility was to develop a data base for determining spent-fuel dry storage temperature limits by characterizing the oxidation behavior of light-water reactor (LWR) spent fuels in air. These data are needed to support licensing of dry storage in air as an alternative to spent-fuel storage in water pools. They are to be used to develop and validate predictive models of spent-fuel behavior during dry air storage in an Independent Spent Fuel Storage Installation (ISFSI). The present licensed alternative to pool storage of spent fuel is dry storage in an inert gas environment, which is called inerted dry storage (IDS). Licensed air storage, however, would not require monitoring for maintenance of an inert-gas environment (which IDS requires) but does require the development of allowable temperature limits below which $\mathrm{UO}_{2}$ oxidation in breached fuel rods would not become a problem. Scoping tests at PNL with nonirradiated $\mathrm{UO}_{2}$ pellets and spent-fuel fragment specimens identified the need for a statistically designed test matrix with test temperatures bounding anticipated maximum acceptable air-storage temperatures. This facility was designed and operated to satisfy that need.

Because the test program involved significant quantities of irradiated fuel, the experiments had to be performed remotely in shielded hot cells with mechanical manipulators and an overhead crane. Because the hot cells were a) ready contaminated, it was also necessary to install all test equipment remotely. Thus a major design consideration was the installation of equipment and the conduct of experiments in a remote environment. Specifically, the following systems were installed in this facility:

- An oxidation oven system which houses multiple oven units for the simultaneous testing of numerous spent-fuel specimens at carefully controlled test temperatures. The system was modular in design to provide for ease of installation. 
An atmosphere control system which enables operators to control the initial composition and humidity of the cover gas in each oven and to periodically sample the cover gas.

- Lead shielded CsCl gamma irradiation sources to generate the highgamma radiation fields predicted for dry storage.

- A welding system to fuse Zircaloy end caps to spent-fuel-rod segments and a helium leak check system to qualify those welds. A drill fixture to machine artificially induced breaches into spent-fuel-rod segments.

- A laser micrometer to accurately measure the diameter of the spentfuel-rod segments to determine the cladding deformation at the defect site as a function of time and temperature.

A computerized data acquisition system to interface with the laser micrometer system.

- A hot cell periscope to allow periodic visual and photographic examinations of the spent- $\mathrm{UO}_{2}$-fragment specimens and spent-fuel-rod segments.

Spent fuel from five different sources was acquired to form the test matrix 0xidation tests with 144 spent- $\mathrm{UO}_{2}$-fragment specimens and 33 spentfuel rod segments were initiated between December 1985 and March 1986 at temperatures ranging from $135^{\circ}$ to $230^{\circ} \mathrm{C}$ with atmospheric dewpoints of $0^{\circ} \mathrm{C}$, $+20^{\circ} \mathrm{C}$ or $+40^{\circ} \mathrm{C}$. End caps were successfully welded on each of the spent-fuelrod segments and an artificially induced breach was machined into each segment. In 1987, these segments were introduced to the ongoing oxidation tests to generate data on cladding deformation and/or failure from spent-fuel oxidation resulting from exposure to air at the cladding breach or defect site.

As of December 1988, the equipment has met all of the operations requirements originally established, and the oxidation tests are still in progress. These tests have permitted the simultaneous generation of numerous 
data points on the oxidation behavior of spent fuel at a range of temperatures. These data include weight gain and cladding deformation measurements, and will provide the primary data base for determining acceptable temperature limits for dry air storage. 


\section{ACKNOWLEDGMENTS}

This work was supported by the U.S. Department of Energy, Office of Civilian Radioactive Waste Management, through the Commercial Spent Fuel Management Division, Richland Operations Office. The project was managed by the Pacific Northwest Laboratory (PNL) Commercial Spent Fuel Management (CSFM) Program Office.

The authors express appreciation to the following individuals for their contributions:

E. R. Gilbert - Developed much of the design criteria for this equipment, has been the project manager since the inception of this work, and provided technical input and technical review of this manuscript.

R. S. Holeman and L. J. Dunn - Installed and are currently operating these systems.

C. M. Andersen - Procured the necessary parts and prepared the drilling system for hot cell operation.

M. L. Elliott - Procured the necessary parts, wrote the operating procedure, and tested and operated the He Leak Detection System.

B. J. Wrona - Provided technical input and coordination of this manuscript.

S. L. Phillips - Prepared this manuscript for publication.

C. Hooker and R. T. Hogan - Performed the gamma radiation measurements. 


\section{CONTENTS}

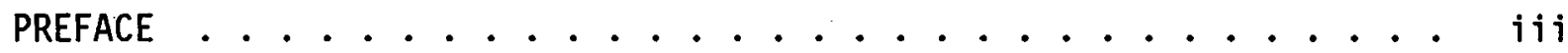

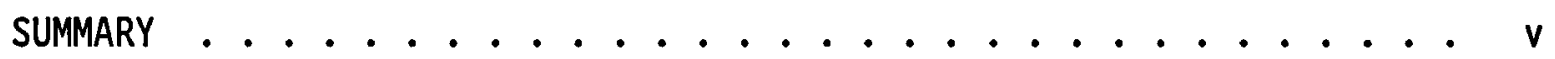

ACKNOWLEDGMENTS .................... . . ix

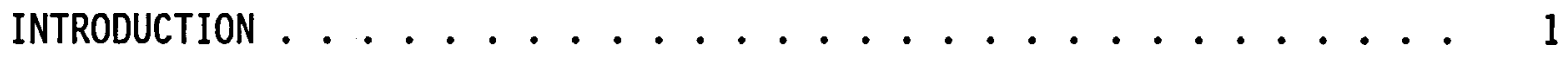

EXPERIMENTAL DESIGN REQUIREMENTS ............... 3

DESCRIPTION OF SPENT FUEL OXIDATION TEST SYSTEMS . . . . . . . 5

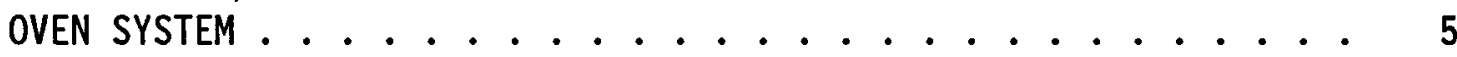

ATMOSPHERE CONTROL SYSTEM ............... 10

CSCI GAMMA IRRADIATION SOURCE ............... 12

WELDING SYSTEM ....................... 13

DRILLING SYSTEM ........................ 19

LASER MEASUREMENT SYSTEM . . . . . . . . . . . 23

HOT-CELL PERISCOPE SYSTEM . . . . . . . . . . 25

EXPERIMENTAL PROCEDURE AND RESULTS ............... 31

TESTING OF FRAGMENTS .................... 32

TESTING OF SEGMENTS ................... 33

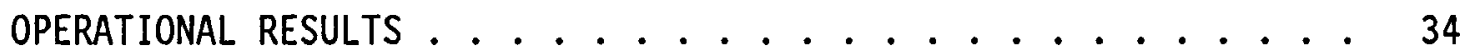

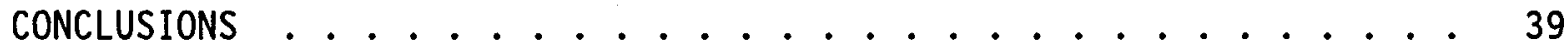

REFERENCES .............................. 41 


\section{FIGURES}

1 Front View of Oxidation Test Oven Rack ........... 6

2 Rear View of 0xidation Test Oven Rack ........... 7

3 0xidation Test oven Interior ................. 9

4 Atmosphere Control System . . . . . . . . . . . 11

$5 \mathrm{CsCl}$ Gamma Irradiation Source Holder. . . . . . . . . . . 14

6 CsCl Gamma Radiation Source Holder and Oven System Installed in Radiochemical Hot Cell ........... 15

7 Spent-Fue1-Rod Segment TIG Orbital Head Welder . . . . . . 17

8 Schematic of Spent-Fue]-Rod Segment, End Cap, and Stainless Steel Plug .............. 20

9 Drilling System Components ............. 21

10 Schematic of Fuel-Rod Segment Drilling System . . . . . . 22

11 Laser Measurement System . . . . . . . . . . . . 24

12 Laser Beam Split by Spent-Fuel-Rod Segment . . . . . . . 26

13 Typical Fuel-Rod Segment Diameter Profile Data . . . . . . . 27

14 Typical Detailed Fuel-Rod Segment Diameter Profile Data . . . . . 28

15 Typical Photographs of Spent-Fuel Oxidation Specimens . . . . 30

16 Typical Rod Cutting Diagram . . . . . . . . . . 32

17 Weight Gain of Spent-Fuel-Fragment Specimens . . . . . . 35

18 Spent-Fuel-Rod Segment with $\mathrm{Cladding} \mathrm{Strain} \mathrm{and} \mathrm{Cracking} \mathrm{.} \mathrm{.} \mathrm{.} 36$ 


\section{TABLES}

1 Radiation Dose Rate Measurement Data ... . . . . . 16

2 Spent Fuel 0xidation Test Specimen Fuel Sources ........ 31 


\section{INTRODUCTION}

This report describes the design and operation of equipment installed in the spent-fuel oxidation test facility at the Pacific Northwest Laboratory(a) (PNL) to test a statistically designed matrix of spent-fuel specimens and to test parameters for characterizing the oxidation behavior of light water reactor (LWR) spent fue1. This work is being supported by the U.S. Department of Energy, Office of Civilian Radioactive Waste Management through the Commercial Spent Fuel Division, Richland Operations Office. The project is managed by the Commercial Spent Fuel Management Program Office at PNL.

This report is the first volume of a four volume series entitled Storage of Spent Fuel in Air. The following are the titles of the four volumes:

Volume I - Design and Operation of an Experimental Facility for Conducting Spent Fuel Oxidation Tests

Volume II - Results from Spent Fuel 0xidation Tests in Air

Volume III - Characterization of 0xidation LWR Spent Fuel

Volume IV - Recommended Temperature Limits for Storing LWR Spent Fuel in Air.

The objective of the spent-fuel oxidation tests was to characterize the oxidation behavior of spent- $\mathrm{UO}_{2}$ fragments and intentionally defected spentfuel-rod segments in air as a function of time and temperature. The data generated by these tests are to be used to develop and validate predictive models of spent-fuel behavior during dry air storage in an Independent Spent Fuel Storage Installation (ISFSI).

Storage of spent fuel in air is attractive because it eliminates the need for monitoring to verify sustained inertness of the atmosphere to prevent oxidation. At sufficiently low temperatures, oxidation of $\mathrm{UO}_{2}$ occurs so slowly that it does not lead to gross degradation of spent fuel during the 20- to 40-year period of interim storage. Scoping tests with nonirradiated $\mathrm{UO}_{2}$ pellets and spent-fuel fragments exposed to heated air were

(a) Operated for the U.S. Department of Energy by Battelle Memorial Institute under Contract DE-AC06-76RLO 1830. 
performed to support an industry expectation that spent fuel could be stored in air at temperatures up to $250^{\circ} \mathrm{C}$ (White et a1. 1983). The results of the scoping tests, however, led to the conclusion that oxidation of spent $\mathrm{UO}_{2}$ was too rapid at $250^{\circ} \mathrm{C}$, and that statistically designed long-term tests conducted at temperatures bounding the anticipated peak allowable temperature would be required to determine acceptable temperatures for storing LWR spent fuel in air (Campbel1 et a1. 1987).

It was anticipated that the methodology for deriving acceptable storage temperature limits would parallel that used to develop acceptable conditions for storing spent fuel in an inert gas or nitrogen atmosphere (Cunningham et a1. 1987). A primary difference, though, is that the degrading mechanism in air is oxidation of $\mathrm{UO}_{2}$ at the site of a cladding breach instead of stress rupture of pressurized $\mathrm{cladding} \mathrm{stored} \mathrm{at} \mathrm{higher} \mathrm{temperatures} \mathrm{in} \mathrm{an} \mathrm{inerted}$ ISFSI. The chemical reaction of $\mathrm{UO}_{2}$ with the oxygen in air, and the associated density changes in the reaction products, are described in the following equation (Belle 1961):

$$
\begin{aligned}
& \mathrm{AIR}+\mathrm{UO}_{2} \underset{\text { (heat) }}{\Delta-\cdots} \mathrm{U}_{3} \mathrm{O}_{7} \rightarrow \mathrm{U}_{3} \mathrm{O}_{8} \\
& \begin{array}{llll}
\text { DENSITY }(\mathrm{g} / \mathrm{cc}) & 10.96 & 11.40 & 8.35
\end{array}
\end{aligned}
$$

As the density of the fuel decreases from 10.96 to $8.35 \mathrm{~g} / \mathrm{cc}$, there is a substantial volume expansion of the spent fuel and subsequent fuel pellet disintegration into fine $\mathrm{U}_{3} \mathrm{O}_{8}$ powder. This volume expansion (in excess of $20 \%$ ) of the fuel can create a significant stress on the cladding that can extend or propagate a cladding breach. Subsequently, the extended cladding breach can lead to the release of respirable size $\mathrm{U}_{3} \mathrm{O}_{8}$ powder. Licensing of dry-air storage of spent fuel requires determining the maximum allowable temperature below which the $\mathrm{UO}_{2}$ oxidation will not occur to a significant extent during the anticipated storage time. The spent-fuel oxidation test facility was designed, its equipment installed, and operated to generate the data required to determine the maximum allowable air-storage temperature. 


\section{EXPERIMENTAL DESIGN REOUIREMENTS}

In earlier work at PNL it had been determined that 1) the oxidation behavior of spent fuel and that of nonirradiated $\mathrm{UO}_{2}$ was quite different; and 2) the significant variables that affected oxidation were temperature, fuel microstructure and, to a lesser extent, moisture content of the cover gas (White 1983; Campbell 1987). Thus, to develop the data base required for licensing dry-air storage of spent fuel, the time-temperature dependency of the oxidation of spent fuel from different sources needed to be determined. Because of the relatively short period of time ( $\sim 3$ years) available to develop this data base, and the need to bracket the allowable air-storage temperature to be determined, it was necessary to simultaneously conduct oxidation tests at several different temperatures. Furthermore the following criteria were imposed on the tests:

- The variability in the oxidation behavior of spent fuel from different sources needed to be evaluated. The spent fuel to be used in the tests should be typical of PWR and BWR fuels with low to moderate burnup.

- The initial cover gas composition in each test oven should be controllable and measurable.

- The test temperature of each oven should be controllable (to $\pm 4^{\circ} \mathrm{C}$ ) and continuousiy recorded.

- The specimens in each oven should be exposed to a high $\left(\sim 10^{5} \mathrm{R} / \mathrm{hr}\right)$ gamma radiation field.

- The initial moisture content of the cover gas should be controllable and measurable.

- Operators should be able to periodically sample the cover gas of each oven.

- Operators should be able to periodically remove specimens from the ovens for weighing, visual examinations, and photographing.

- Nonirradiated PNL-produced $\mathrm{UO}_{2}$ pellets should be included as a reference for comparison with previous work. 
Initially, all oxidation tests were with spent-fuel fragments which were to be exposed to air at elevated temperatures with intermittent weight-gain measurements and visual examinations. However, to develop a relationship between weight gain and cladding strain and cracking, short segments of clad irradiated fuel were added to the test matrix. To prepare spent-fuel-rod segments for these tests required the design and development of equipment 1) to weld caps on the ends of the rod segments, 2) to introduce a controlled defect in the cladding of the rod segments, and 3) to measure the diameter specimens to determine cladding strain as a function time and temperature.

Because the test program used significant quantities of irradiated fuel, and because the available hot cell was already contaminated, the equipment was installed, operated and maintained remotely using mechanical manipulators and an overhead crane. 


\section{DESCRIPTION OF SPENT FUEL OXIDATION TEST SYSTEMS}

The following systems were installed in the spent-fuel oxidation test facility: twelve ovens, an atmosphere control system, CsCl gamma irradiation sources, end cap welding system, a drilling system, laser micrometer with data acquisition system, and hot-cell periscope. In this section, detailed descriptions of these systems are presented.

\section{OVEN SYSTEM}

The oven system was installed in the test facility to provide a capability for conducting simultaneous oxidation tests with spent fuel in air or in nitrogen over a range of temperatures. A statistically designed test matrix required a minimum of twelve oxidation test ovens. Twelve spent- $\mathrm{UO}_{2}{ }^{-}$ fragment specimens and one nonirradiated $\mathrm{UO}_{2}$ specimen were to be tested in each oven for a total of 144 specimens. Because of the rapid rates of spent$\mathrm{UO}_{2}$ oxidation above $230^{\circ} \mathrm{C}$, all tests were to be conducted at temperatures below $230^{\circ} \mathrm{C}$. Therefore, the operating temperature range for the ovens needed was specified to be from ambient to $300^{\circ} \mathrm{C}$. A procurement order was placed for thirteen vacuum ovens (twelve operating units plus one spare). Four units were specified to have an operating range to $400^{\circ} \mathrm{C}$ in the event that higher temperature tests in atmospheres other than air would be required.

The complete oven system consisted of 12 stainless steel vacuum ovens mounted six each in two structural racks. Six of the ovens which made up one-half of the test system are shown in Figures 1 and 2 . The ovens were mounted into the racks before being installed in the hot cell. Each rack is a single module containing all of the wiring, valving and piping required to control and monitor the operation of each oven. On the front face of each rack are thermocouple plugs for measuring oven temperature, a humidification tank power plug, oven power connections, pressure transmitter power plugs, power to solenoids, cover gas control solenoids, gas sampling control solenoids, the vacuum control solenoids, and pressure transducers for each of the six ovens. All of these components were mounted on the rack in locations which were within reach of the hot-cell manipulators. Because of the high gamma radiation level, instruments such as temperature and pressure 


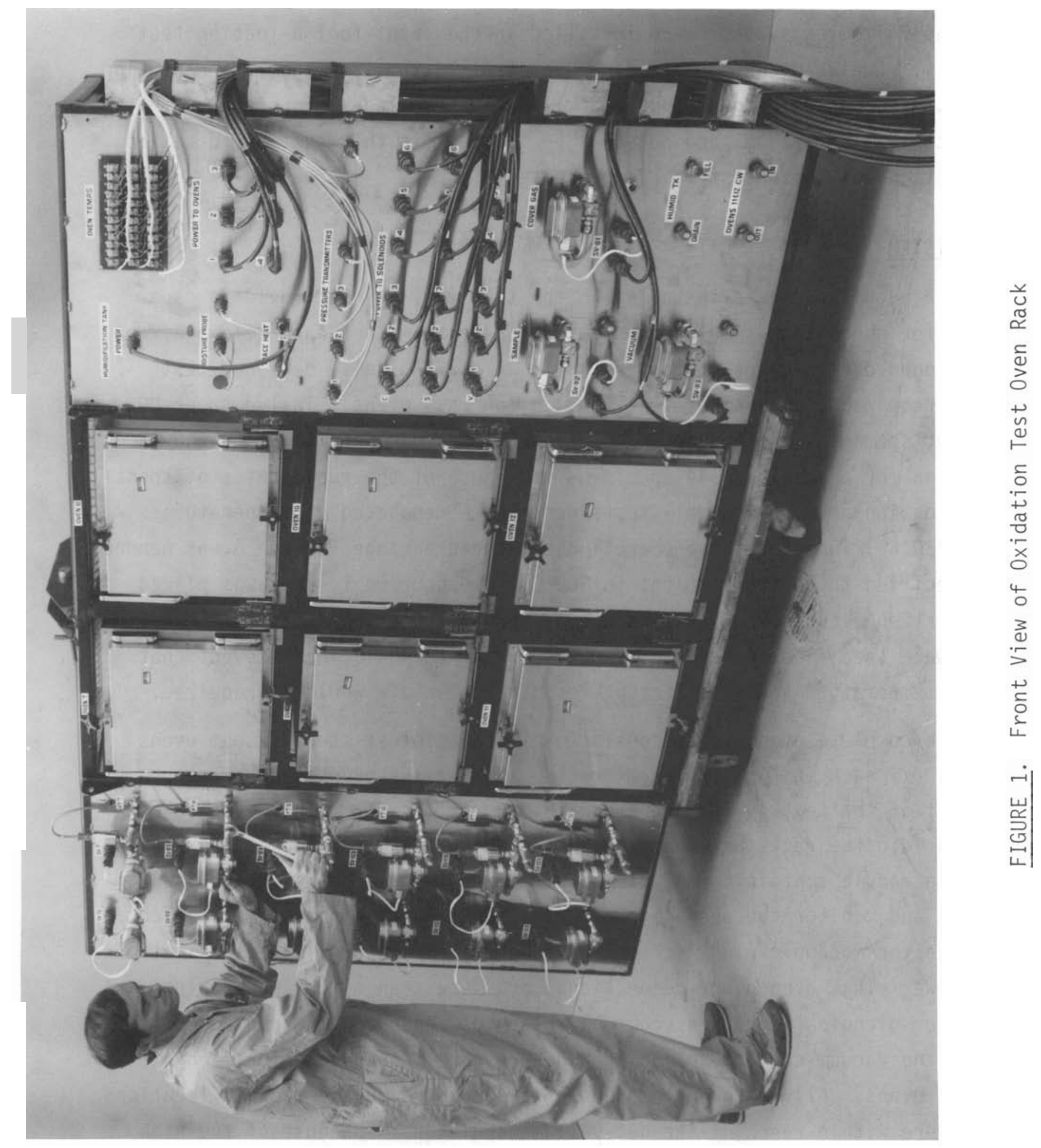




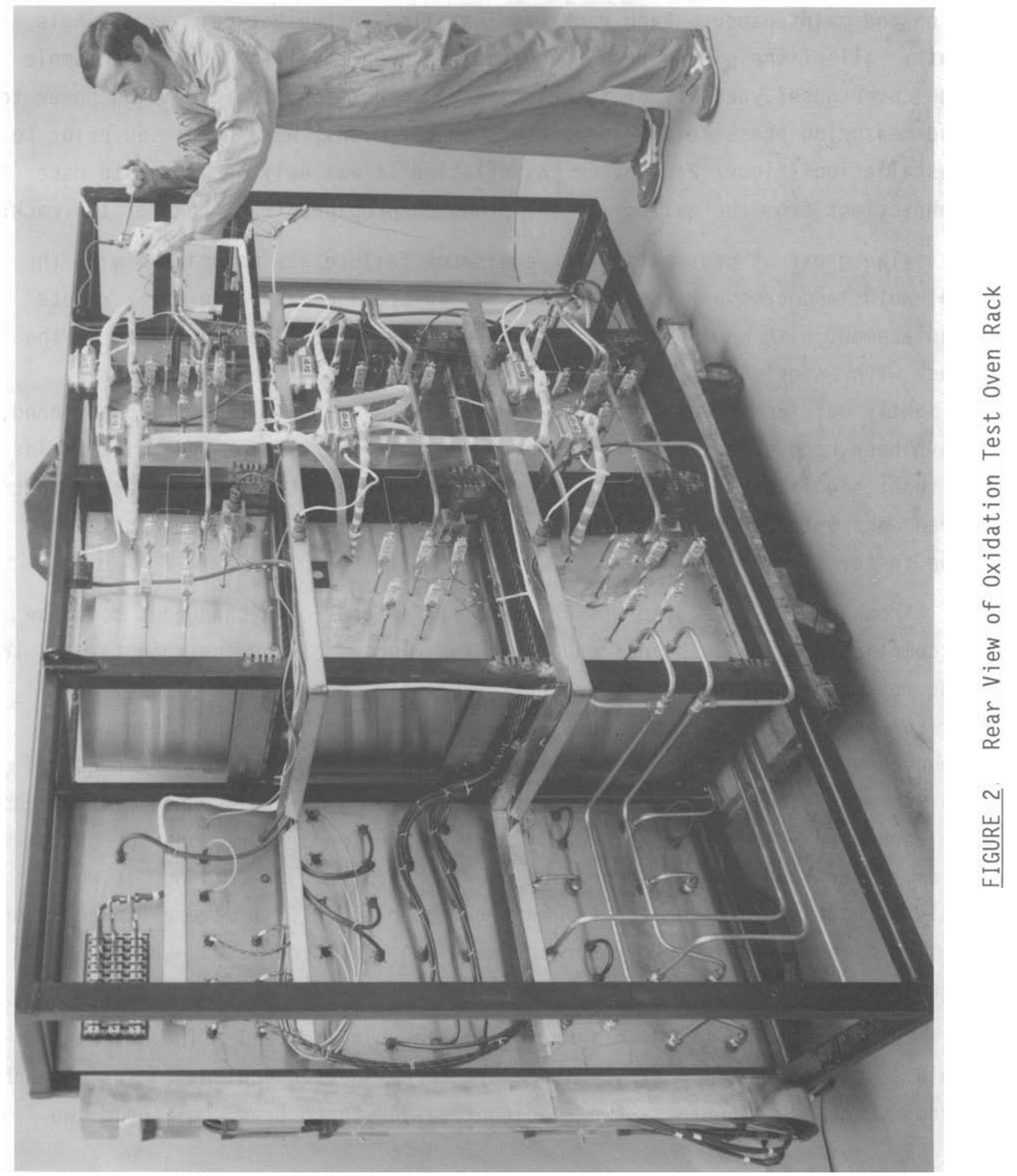


recorders, power supplies, and oven controllers were located in the operating gallery. The primary function of the oven racks was to facilitate installation and maintenance. Each rack was installed in the hot cell as a single unit: all of the piping runs to evacuate and backfill the ovens and sample the cover gases, and all of the electrical connections for providing power to and measuring pressure and temperature in the ovens, were completed prior to installation (Figure 2). After installation it was only necessary to make connections from the gallery to the prewired/prepiped front face of the rack.

The greatest possibility for equipment failure was associated with the solenoids and pressure transducers. So, to provide easy access for remote replacement with manipulators, they were installed on the front face of the rack with Swagelok fittings on a "U" shaped piping run which extended slightly out from the rack face. Ovens and thermocouples, on the other hand, have been used extensively for long periods of time in high-radiation fields without significant equipment failures. Therefore, it was not expected that oven and/or thermocouple failures would be a problem during the course of the tests.

However, a spare oven was ordered. If needed, oven changeout could be accomplished remotely by disconnecting the electrical and instrument leads to the rack and rotating the entire rack $180^{\circ}$ to disconnect the piping, electrical and instrument leads to a failed oven. That oven could then be removed and the spare unit installed. The same procedure would be required to replace a thermocouple. However, there were five thermocouples installed in each oven--three to continuously monitor the temperature, one to control oven temperature and one to provide over-temperature protection. It would only be necessary to replace failed thermocouples only if several in one oven failed. To date neither oven or thermocouple replacements have been required.

A schematic of the oven interior is shown in Figure 3 . The internal volume is $0.042 \mathrm{~m}^{3}\left(1.5 \mathrm{ft}^{3}\right)$. There are three shelves equispaced inside each oven. Each shelf contains two sliding trays and each tray could hold two 


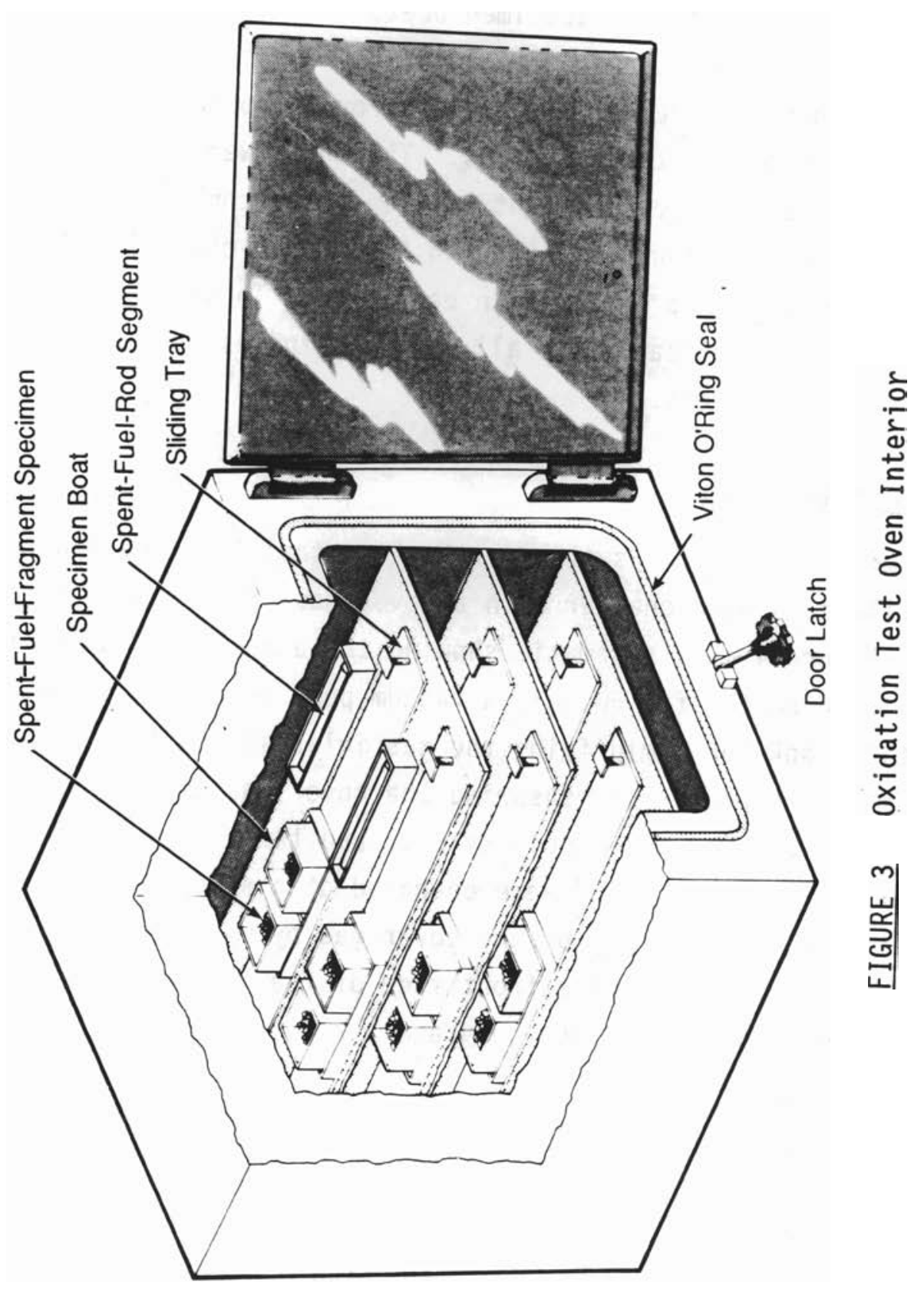


specimen boats. The empty space on either side and between the sliding trays provided room for the spent-fuel-rod segments. The vertical post at the near end of each tray facilitates movement of the tray with manipulators, thus minimizing the jarring of specimen boats and possible loss of sample. The specimen boats on each shelf were located close together to minimize within-shelf temperature variations and to provide approximately the same gamma dose rate to all of the specimens. The boats were fabricated from aluminum to minimize the total weight of the sample container. To determine the contribution of aluminum oxidation to the weight changes being measured, an empty specimen boat was included in each oven. To date, weight changes in boats have been insignificant, and all weight gain has been attributed to oxidation of $\mathrm{UO}_{2}$ specimens.

\section{ATMOSPHERE CONTROL SYSTEM}

The atmosphere control system in the test facility provided the capability to fill each oven chamber with a cover gas of known composition and dew point. Figure 4 is a schematic showing the atmosphere control system. The system included the following: a vacuum pump to evacuate the ovens, a humidification tank for humidifying the gas inlet stream to the ovens, a hygrometer moisture probe for measuring the cover gas dew point, a cover gas sampling system, a cover gas supply system, and the associated piping for all of these components. The ovens were operated at a slightly positive pressure of air to ensure the integrity of the cover gas by minimizing inleakage. A Viton gasket was inserted in the front face of the oven to provide a leaktight connection between the oven body and the oven door.

Bottled air was used as the source of air for each oven, and a sample from each bottle was analyzed by mass spectrometry before being used. Thus the initial cover gas composition was known. To obtain the cover gas, each oven is evacuated and backfilled several times to remove moisture and residual contaminants before heating the ovens. The dew point was controlled between $0^{\circ}$ and $+40^{\circ} \mathrm{C}$, and measured with a condensation dew point hygrometer. The initial dew point in each oven was controlled to provide the data needed to assess of the effect of moisture on fuel oxidation. Three dew points were 


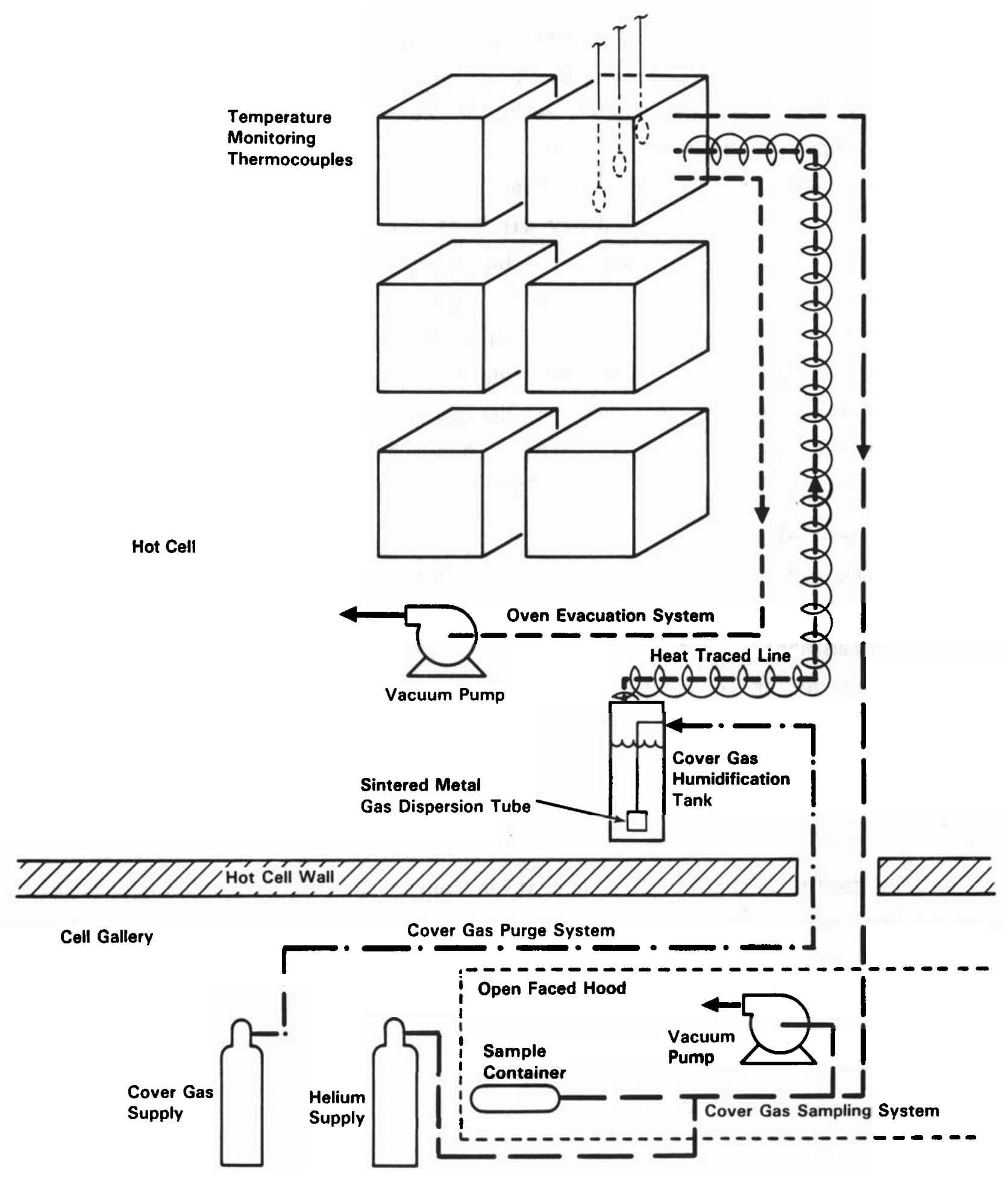

FIGURE 4. Atmosphere Control System 
selected for these tests: $0^{\circ} \mathrm{C}$ (below ambient), $20^{\circ} \mathrm{C}$ (ambient), and $+40^{\circ} \mathrm{C}$ (above ambient). To obtain gas dew points above ambient temperature $\left(-30^{\circ} \mathrm{C}\right)$, the supply gas is saturated with water in the humidification tanks (one tank for each rack). The tanks and lines to the ovens are heated to obtain the desired dew point $\left(+40^{\circ} \mathrm{C}\right)$. Below ambient temperature, dew points were obtained by routing compressed dry air from the inlet gas header and splitting the air into two streams. One stream passes through a humidification tank and saturated to a dew point equal to the tank temperature. The second stream bypassed the humidification tank, was combined with the first stream at the tank outlet, and then routed to the ovens. This stream was monitored with the moisture probe or dew point analyzer. The ratio of flow rates for the two streams was varied with metering valves to obtain the specified dew point $\left(0^{\circ} \mathrm{C}\right.$ or +20$)$. This procedure has been accurate to $\pm 2^{\circ} \mathrm{C}$.

In parallel with the cover gas supply line is a sampling line, a second vacuum pump, and a sample container. To obtain a cover gas sample, the sampling system was evacuated, purged with helium gas to remove air and other contaminants and then re-evacuated. The solenoid valve to the oven was then opened and cover gas flows into the evacuated sample container. The container was disconnected and transferred to an analytical laboratory for analyses.

\section{CSCI GAMMA IRRADIATION SOURCE}

The design criteria for a radiation source for the oxidation tests on spent fuel was the need to simulate the gamma field in a dry-storage cask, which was estimated to be approximately $1 \times 10^{5} \mathrm{R} / \mathrm{h}$. To provide the radiation source, twelve Waste Encapsulation Storage Facility (WESF) cesium chloride capsules were borrowed from Westinghouse Hanford. Each capsule contains about 50,000 curies of cesium. To achieve the required high-dose rates, a separate capsule had to be located outside the front door of each oven. This was accomplished by stacking three capsules in a cylindrical container in front of the three vertical ovens in each rack. This container needed to be easily removed by a crane to permit access to the ovens. It was al so necessary to minimize gamma-dose rates from these capsules to the instrumentation located on the oven rack and to the other equipment in the 
hot-cel1. This was achieved by fabricating a $\mathrm{CsCl}$ source holder which was a $1.7-\mathrm{m}$ (66 in.) long cylinder with a $45^{\circ}$ wedge removed along the length of the cylinder. The cylinder was fabricated from $7.6-\mathrm{cm}-(3 \mathrm{in.-})$ dia schedule-40 pipe surrounded by a $19.1 \mathrm{~cm}-(7.5 \mathrm{in.-})$ dia jacket. The space between the jacket and the pipe was filled with lead shot (Figure 5). The unshielded $45^{\circ}$ wedge was oriented toward the ovens, thus providing the dose to the ovens and shielding for the rest of the equipment in the facility (Figure 6). The source holder could be routinely moved to one side of the hot cell with the overhead crane to permit the ovens to be opened and specimens removed for examination.

Prior to test start-up, the actual radiation levels from a single Cs-137 capsule were measured at five different points. These points were labeled $A, B, C, D$, and $E$ as shown in Table 1. Exposure rates ranged from a high of $3.3 \times 10^{5} \mathrm{R} / \mathrm{hr}$ at Point $A$ to a low of $6.6 \times 10^{4} \mathrm{R} / \mathrm{hr}$ at Point B. Point $A$ was taken at the approximate midpoint along the capsule's length with the detector in contact with the cylinder wall. Points B, C, and D were taken at a distance of approximately $0.25 \mathrm{~m}(10 \mathrm{in}$.) from the cylinder with the detector positioned inside the oven. The oven door was open for measurements $A, B, C$ and $D$; the source was positioned upright and directly in front of the oven cavity. The Point E measurement was taken with the oven door partially closed and between the detector and the oven cavity. Ambient environmental conditions were considered and factored into the values shown. A11 measurement and test equipment used in the study carried calibrations traceable to the National Bureau of Standards (NBS). Each exposure rate value reflected the average of four measurements taken at that point. Because all the capsules had approximately the same curie content, these sources provided suitable gamma radiation fields for these tests.

\section{WELDING SYSTEM}

The primary function of the spent-fuel-rod segment welding system used in the oxidation test facility was to provide leak-tight welds of end caps to short segments of spent fuel. Thus exposure of the fuel to air could only be via the artificially induced breach and not the end caps. The welding 


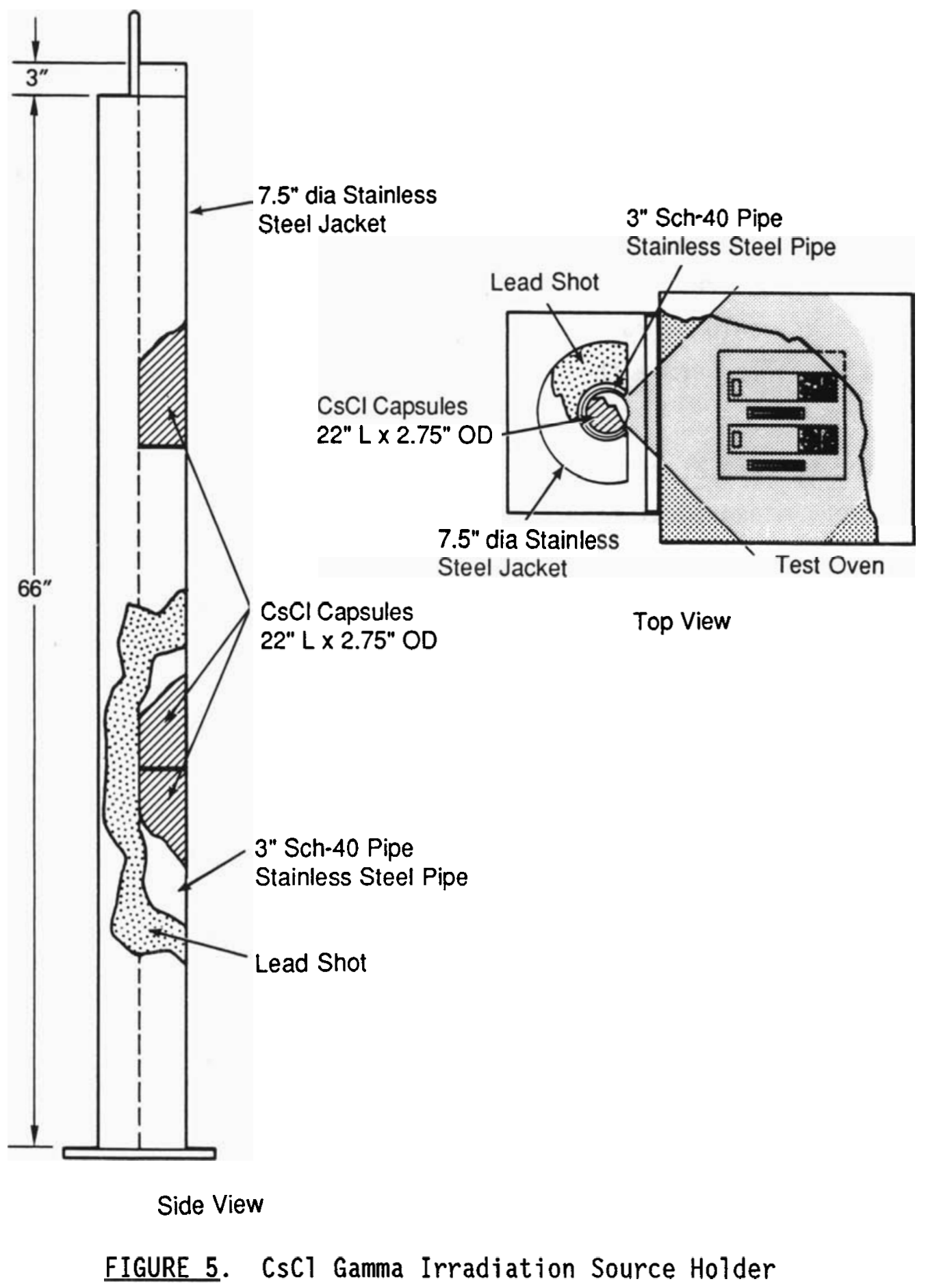




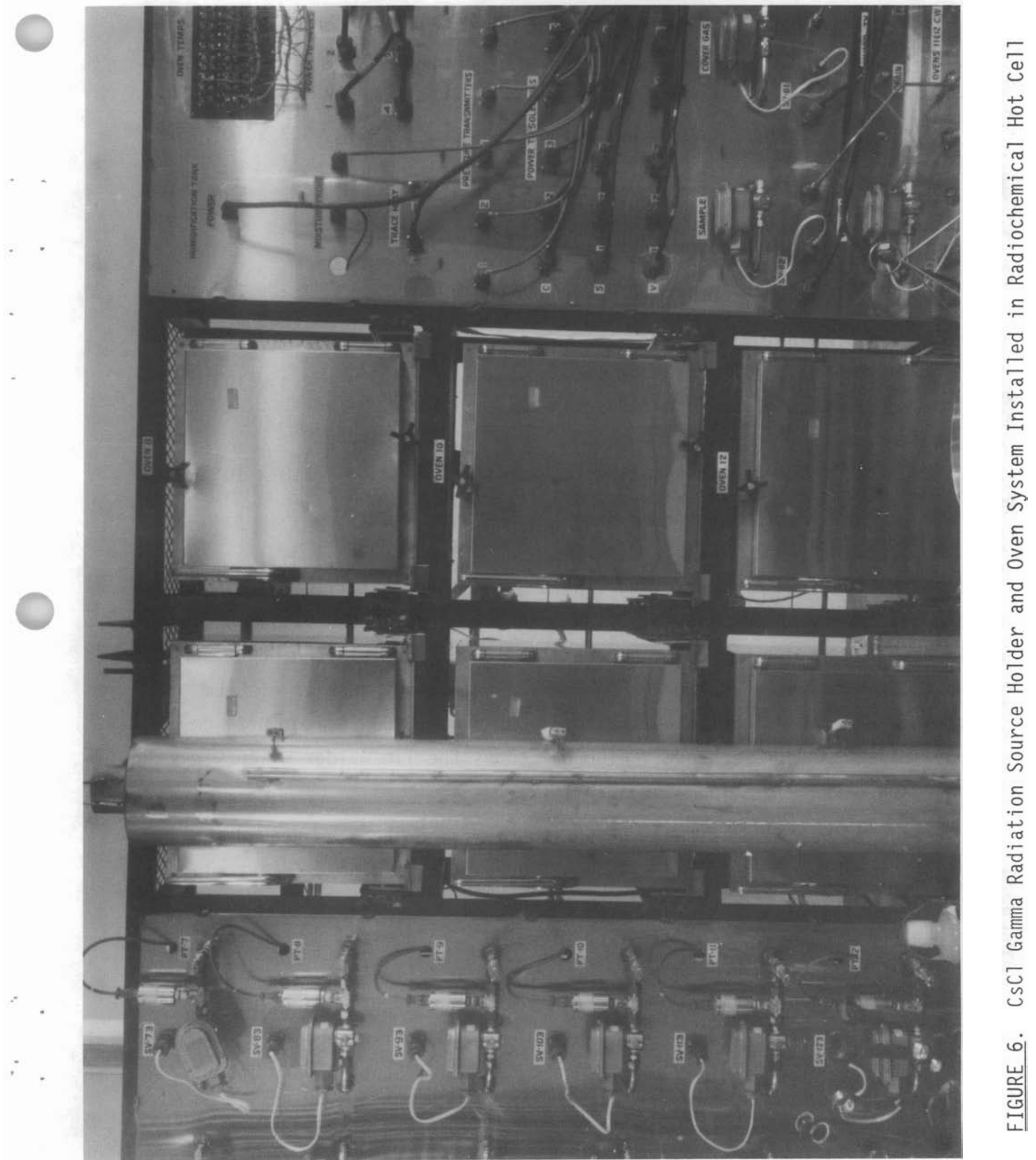




\section{TABLE 1. Radiation Dose Rate Measurement Data}

Measurement

\section{Point}

A

B

C

D

$E$

\section{Geometry}

Front Midpoint of Cylinder; detector in contact

Top Shelf; detector approximately $0.25 \mathrm{~m}$ (10 in.) from source, inside of oven

Middle Shelf; detector approximately $0.25 \mathrm{~m}$ (10 in.) from source, inside of oven

Bottom Shelf; detector approximately $0.25 \mathrm{~m}$ (10 in.) from source, inside of oven

Door against cylinder; detector in contact with opposite side of door, outside of oven
Exposure Rate $(R / h r)$

$3.3 \times 10^{5}$

$6.6 \times 10^{4}$

$7.3 \times 10^{4}$

$8.3 \times 10^{4}$

$1.8 \times 10^{5}$

apparatus consisted of a rotating tip-tungsten inert-gas (TIG) weld head, an inert gas supply, a power supply, and connecting cables and gas lines. The weld head was installed in the hot-cell while the controls and power supply were located in the operating gallery. The weld head consists of $8-\mathrm{cm}$ (3.2-in.) dia rotor that accepts either a $0.16-\mathrm{cm}(0.06-$ in.) or $0.24-\mathrm{cm}$ (0.09-in.) tungsten electrode. Figure 7 shows the TIG welder which was mounted on a heavy platform for stability.

The weld head is designed so that the electrode rotates around the stationary rodlet which is held in position by the weld head insert clamps. A critical dimension is the gap between the tip of the electrode and the weld surface. Prior to welding, a calibration rod was inserted in the weld head. Set screws were tightened when the electrode contacted the calibration rod to set the position of the electrode. In this manner, a 0.08-cm (0.03-in.) gap between the electrode and the end cap was ensured. Alignment of the weld joint with the electrode was maintained by physical stops on the insert clamps. 


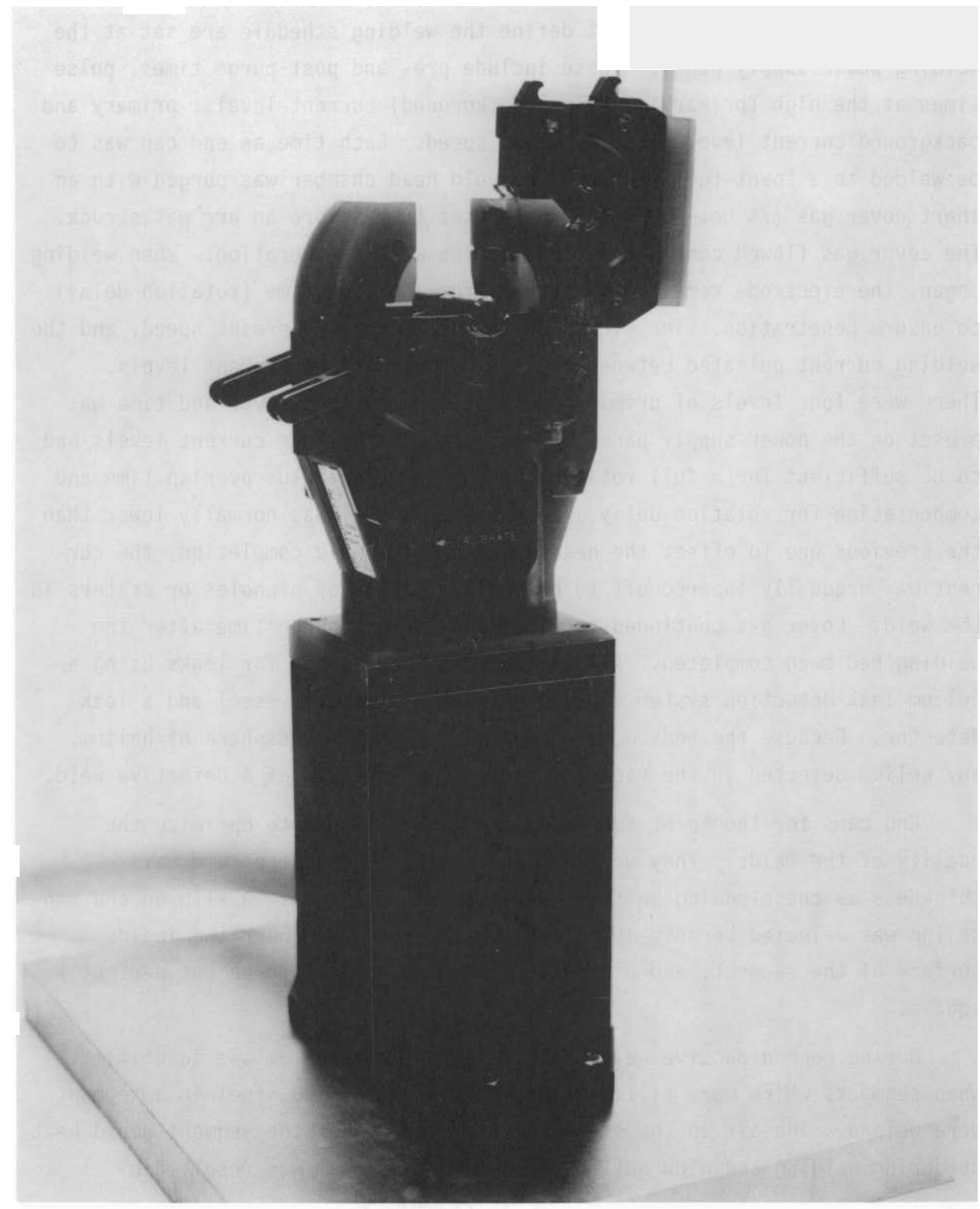

FIGURE 7. Spent-Fuel-Rod Segment TIG Orbital Head Welder 
A number of parameters that define the welding schedule are set at the welding power supply panel. These include pre- and post-purge times, pulse times at the high (primary) and low (background) current levels, primary and background current levels, and rotation speed. Each time an end cap was to be welded to a spent-fuel segment, the weld head chamber was purged with an inert cover gas (7\% He, 93\% Ar) for a preset time before an arc was struck. The cover gas flowed continuously during the welding operation. When welding began, the electrode remained stationary for a preset time (rotation delay) to ensure penetration. The electrode then rotated at a preset speed, and the welding current pulsated between primary and background current levels. There were four levels of primary current; each current level and time was preset on the power supply panel. Total time of the four current levels had to be sufficient for a full rotation of the electrode plus overlap time and compensation for rotation delay. Each primary level was normally lower than the previous one to offset the heat input. After weld completion, the current was gradual7y tapered off to prevent formation of pinholes or craters in the weld. Cover gas continued to flow for a preset purge time after the welding had been completed. A11 welded rods were tested for leaks using a helium leak-detection system consisting of a 2-1 vacuum vessel and a leak detector. Because the rods were welded in a partial atmosphere of helium, any helium detected in the vacuum vessel was the result of a defective weld.

End caps for the spent-fuel segments were designed to optimize the quality of the welds. They were designed to have about the same wall thickness as the cladding on the spent-fuel-rod segments. A slip-on end cap design was selected because it eliminated the need to deburr the inside surface of the segment, and did not require the segment to be cut perfectly square.

During nonradioactive weld tests, a potential problem was identified when segments which were filled with sand to simulate $\mathrm{UO}_{2}$ fuel in a segment were welded. The air in the small space at the end of the segment would heat up during welding and blow out the weld. This problem was resolved by 
June 16,1989

Recipients of PNL-6640

Dear Recipients:

SUBJECT: ERRATA FOR PNL-6640 $\mathrm{Vol}$. 1

RE: Thornhill, C. K., T. K. Campbel1, and R.E. Thornhill. 1988. Design and Operation of a Spent Fuel Oxidation Test Facility. PNL-6640, prepared for the U. S. Department of Energy by Pacific Northwest Laboratory.

On page 19 of this report, and indicated in Figure 8 on page 20, it is incorrectly stated that a stainless steel plug was used to dissipate heat during welding of zircaloy end caps.

This statement is incorrect: The plugs were fabricated from the same bar stock material as all of the end caps were. Please change text to agree with this restatement.

Attached is a corrected copy of Figure 8, page 20, to replace the existing figure.

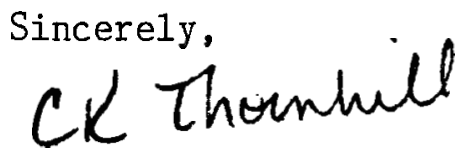

C. K. Thornhill 
inserting a stainless steel plug in the gap (Figure 8). This reduced the size of the air gap and provided a heat sink for dissipating heat built up during welding.

\section{DRILLING SYSTEM}

The objective of the drilling system in the test facility was to introduce a defect of known size into the cladding of each rod segment to simulate a cladding breach. The design criteria for the drill fixture included the need to drill a $0.076-\mathrm{cm}$ ( $0.030 \mathrm{in.})$ dia hole to a controlled depth. This diameter was selected to be consistent with similar work completed by other researchers (Einziger 1983). The hole depth had to be carefully controlled to minimize drilling into the spent fuel and to ensure that the cladding had been completely breached. Because testing of different fuel types was required, it was necessary for the system to penetrate varying cladding thicknesses.

Figures 9 and 10 show the simple remote system that was developed to accomplish this work. The system consists of several drill-bit stops, a drill-bit stop holder, a drill-bit alignment guide, and a drill press. Each drill-bit stop had a $0.1-\mathrm{cm}(0.040-i n$.$) dia hole which was drilled to a$ precise depth. The exact depth of the hole was determined according to the cladding thickness of the rod segment to be breached.

The drill-bit stop holder consisted of a short pipe segment sealed at one end. The drill bit stop was placed in the holder. A $0.076-\mathrm{cm}\left(0.03-\right.$ in. $\left._{\text {. }}\right)$ dia drill bit was placed in the hole in the stop. This assembly was then positioned on the drill press table so that the exposed shank of the drill bit was centered with the keyless chuck of the drill press. The drill chuck was lowered onto the bit and tightened so that the chuck jaws firmly engaged the drill bit shank. During this process, it was necessary to maintain physical contact between the bottom of the chuck jaws and the top of the drill bit stop. Pressure created by a spring in the bottom of the drill-bit stop holder ensured that the stop. was always seated against the chuck jaws. The result was a mounted drill bit extending a precise distance from the bottom of the chuck jaws to the tip of the bit. 


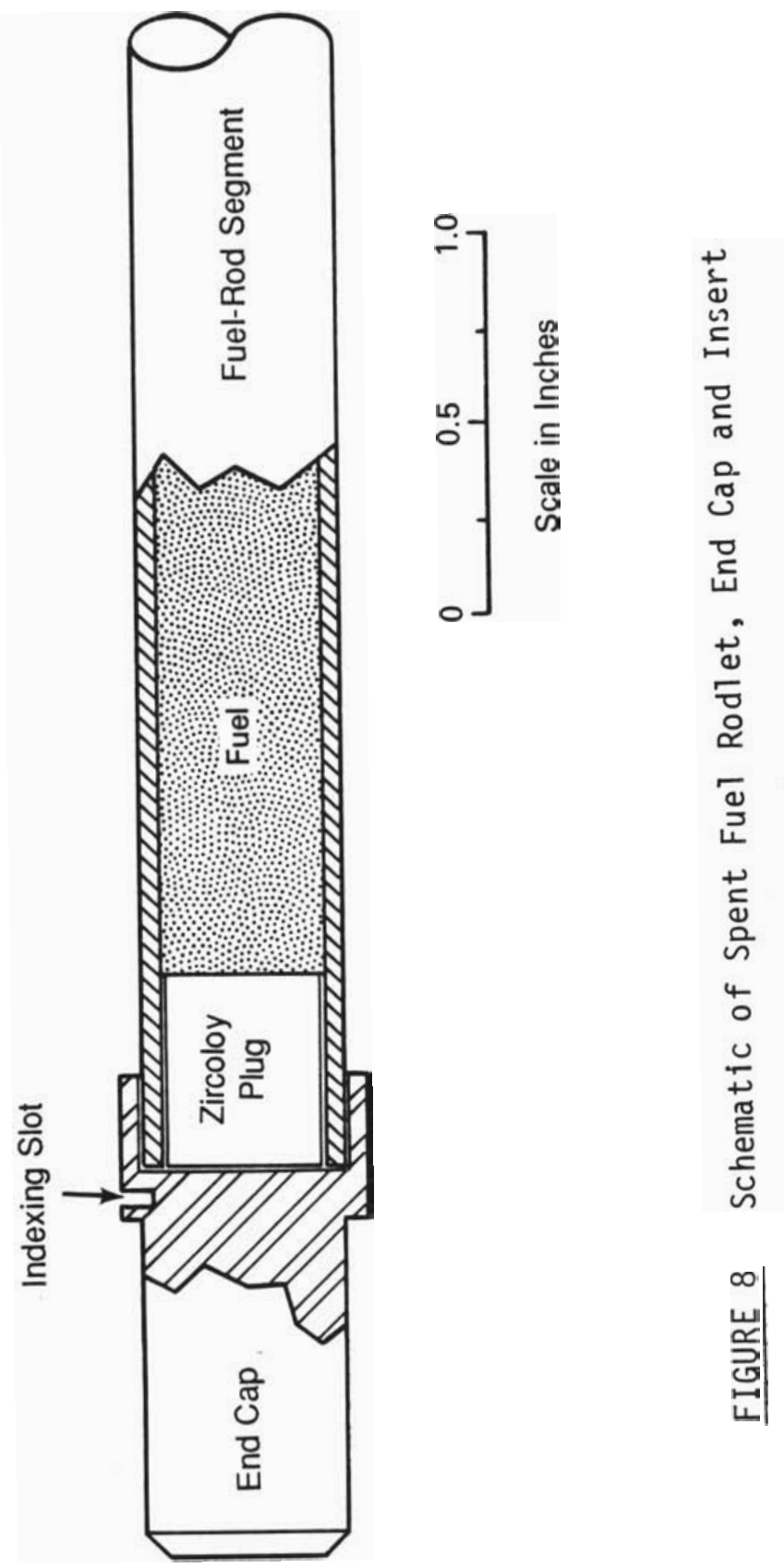




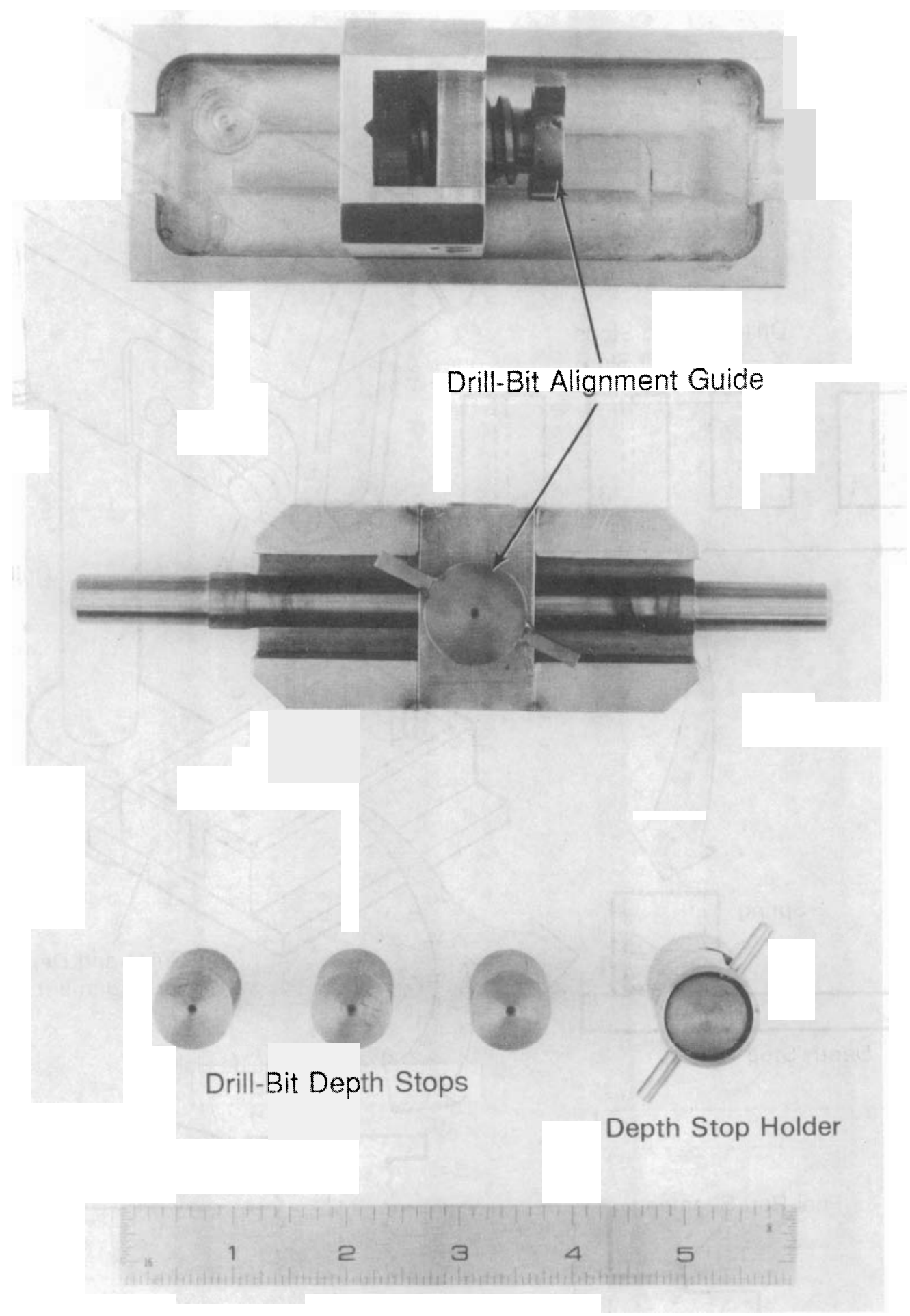

FIGURE 9. Drilling System Components 


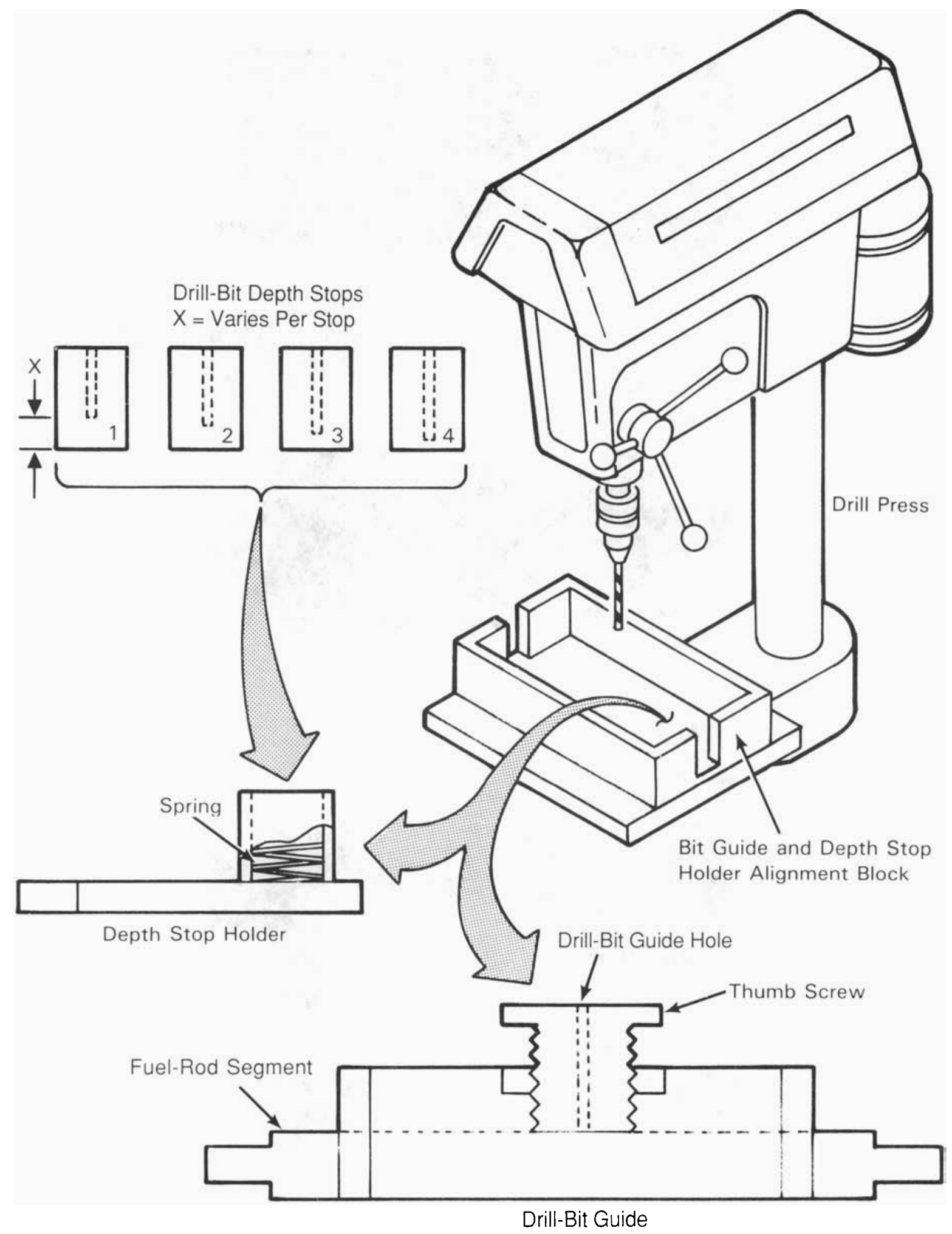

FIGURE 10. Schematic of Fuel-Rod Segment Drilling System 
The drill-bit-alignment guide assembly supported the fuel-rod segment in a horizontal position while being drilled. The assembly was designed so that the threaded cylinder screwed into the base perpendicular to the rod segment, clamping the rod segment to the base and aligning the cylinder through hole with the rod-segment radial centerline. The assembly was then placed on the drill press table. Physical stops on the drill press table were used to position the alignment guide assembly so that the cylinder through hole and the drill bit were on the same centerline. During the drilling operation, the alignment guide eliminated the need to centerpunch the rod segment. The top of the guide also acted as the physical stop which ensured complete penetration of the cladding. Drill bit speeds of 5,800 rpm were used for optimum drilling of Zircaloy cladding while avoiding significant penetration of the fuel. A11 power controls were located in the hot-cell gallery to simplify operation of the dri11. During actual operations, drill-bit breakage was a common occurrence. This problem was somewhat alleviated by replacing carbide-tipped bits with high-speed steel bits.

\section{LASER MEASUREMENT SYSTEM}

The purpose of the laser system in the test facility was to accurately measure cladding dimensional changes of spent-fuel-rod segments. Therefore, a remotely operable laser micrometer measurement system was procured from Westinghouse Hanford. The system consists of a low-power scanning heliumneon laser unit, a computerized data control and acquisition terminal, and an interfacing control panel. (See Figure 11.) The laser head was lead shielded, installed in the hot ce11, and connected to the computer control system via radiation-resistant cables. To further reduce radiation exposure, the unit was installed in an open-faced lead-lined storage bin.

The laser unit contained a rotating mirror and optics that enabled a laser to emit a beam that rapidiy traversed an approximately 1 -in. wide path. At the receiving side of the unit, a photoelectric cell (located at the focal point of the receiving lens) received the scanning signal. Diameters were determined by placing the segment to be examined within the scanning path between the emitting and receiving sides of the unit. Pneumatic chucks mounted to a shop-fabricated table held the spent-fuel-rod 

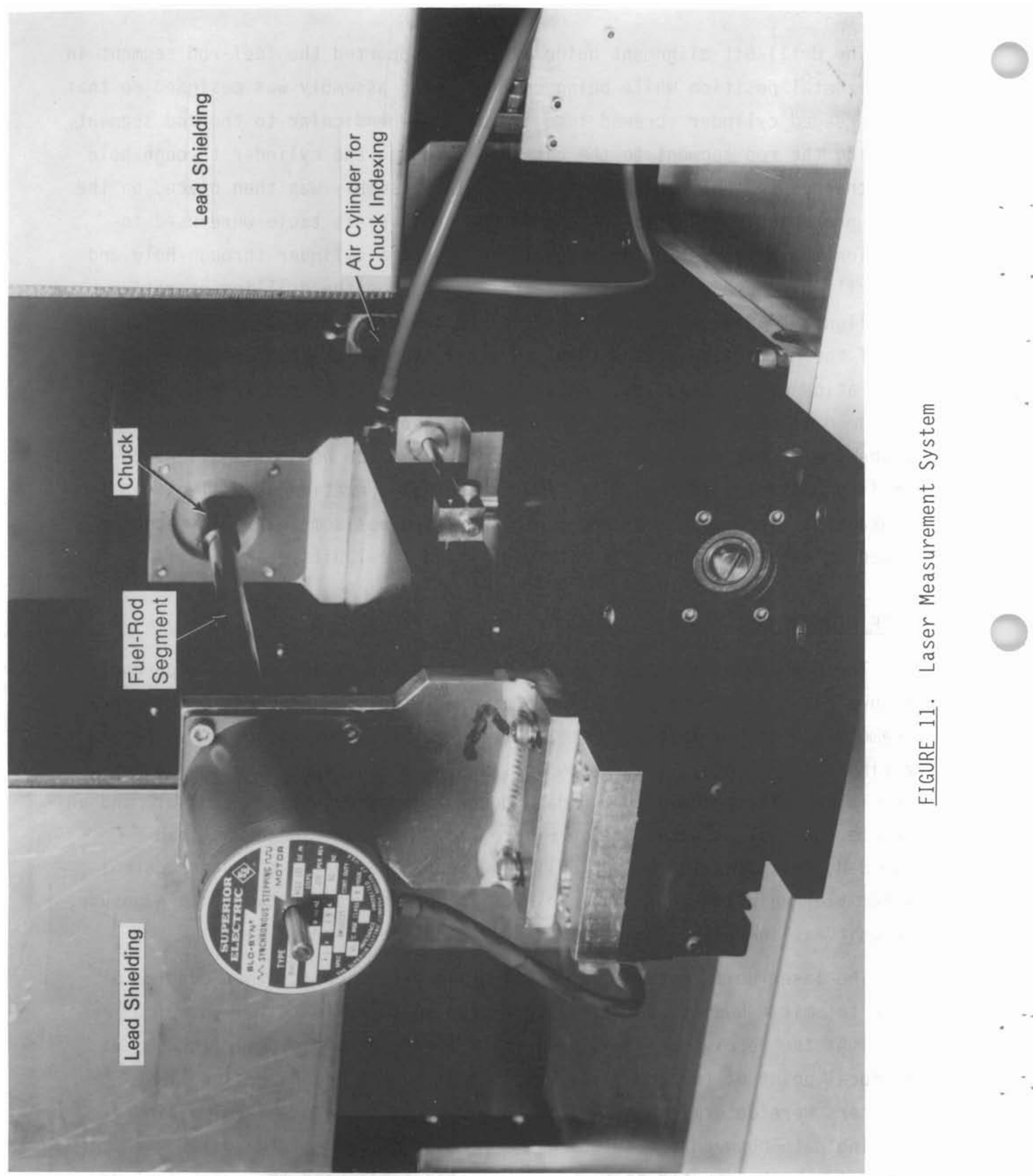

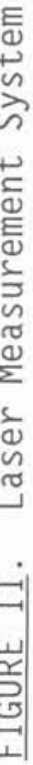


segment in place during scanning. A simulated rod segment positioned in the path of the scanning laser is shown in Figure 12. The laser was capable of measuring diameters to $0.0003 \mathrm{~cm}( \pm 0.0001 \mathrm{in.})$ although $\pm 0.003 \mathrm{~cm}$ $( \pm 0.001 \mathrm{in.})$ was the more practical limit because of surface roughness of the rods. Separate stepping motors controlled the translational and rotational movement of the rod segment.

Following placement into the pneumatic chucks, the spent-fuel-rod segment was positioned to a reference position by manual control of the stepping motors. A $0.16-\mathrm{cm}(0.063-\mathrm{in}$.) wide notched located on one endcap provided both translational and rotational referencing. Following input of the rodsegment data and scanning parameters by the operator, a computer-interfaced control program started rod-segment scanning. The program controlled rotational and translational movement of the rod segment and collected diameter, angular, and positional data during scanning. A calibration rod, similar in diameter to the spent-fuel-rod segment scanned, was measured to verify the diameter measurements. Two profilometry scans of the rod-segment diameters were typically made: 1) a ful1 rod-segment scan at $1.3-\mathrm{cm}(0.5-\mathrm{in.})$ spacing, at 10 to 11 axial locations with each translational position measured every $10^{\circ}$, and 2) a detailed scan at a $0.03-\mathrm{cm}(0.02-\mathrm{in}$.$) spacing covering a 3.8-\mathrm{cm}$ (1.5-in.) long region centered at the site of the artificially induced breach with each translational position measured every $10^{\circ}$. Typical examples of each of these scans at selected angular positions are shown in Figures 13 and 14 .

The computer data acquisition system collected and stored test data from the laser micrometer. The data acquisition system was interfaced with the laser measurement system to store diameter measurements as they were made. This means of recording and storing data served as a convenient format for subsequent data reduction and analyses.

\section{HOT-CELL PERISCOPE SYSTEM}

A wall-mounted hot-cell periscope system in the test facility allowed researchers to visually examine and take photographs of specimens and spentfuel-rod segments. Television viewing was also possible. A record of the physical appearance of the large number of test specimens (144) and rod 


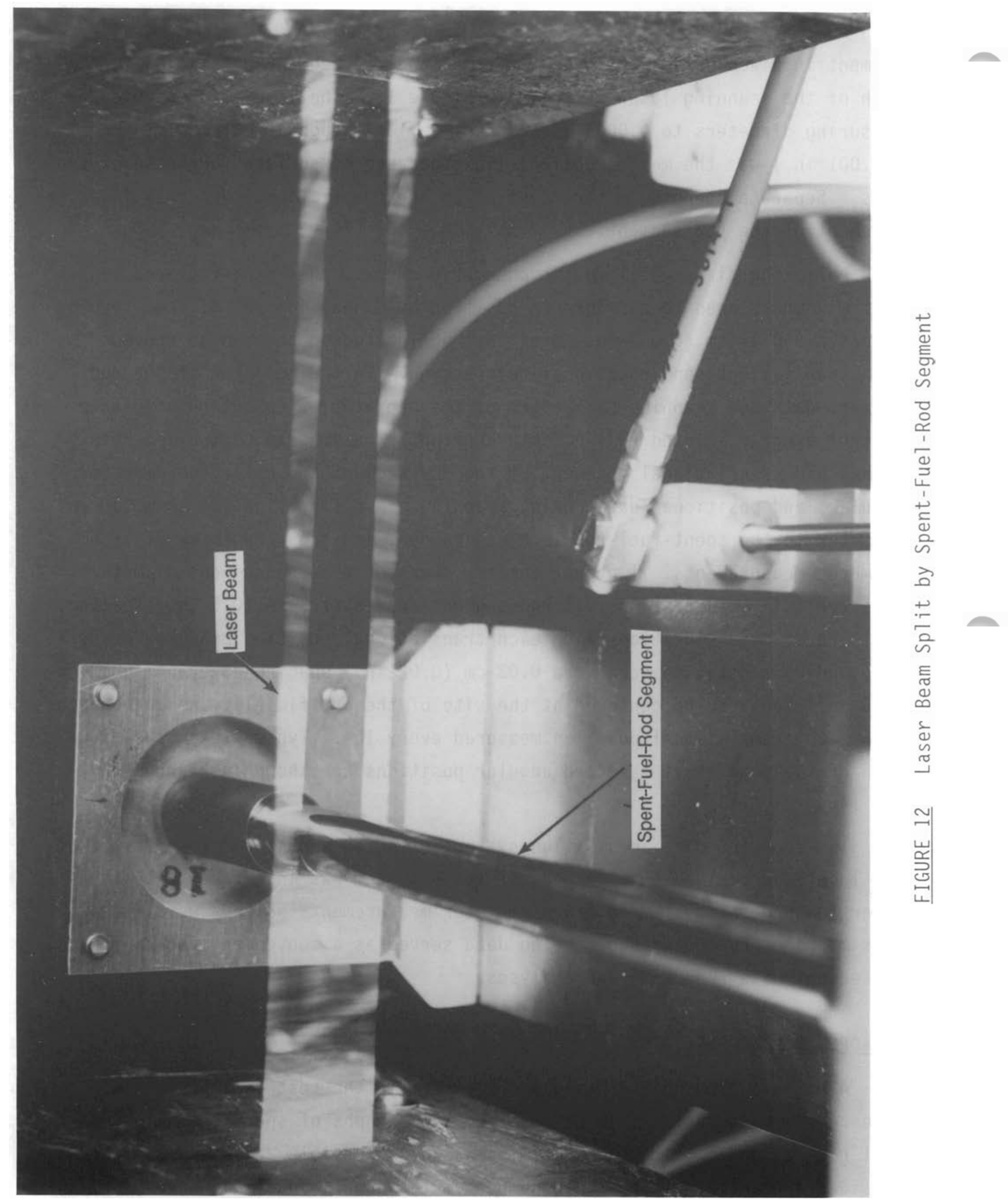




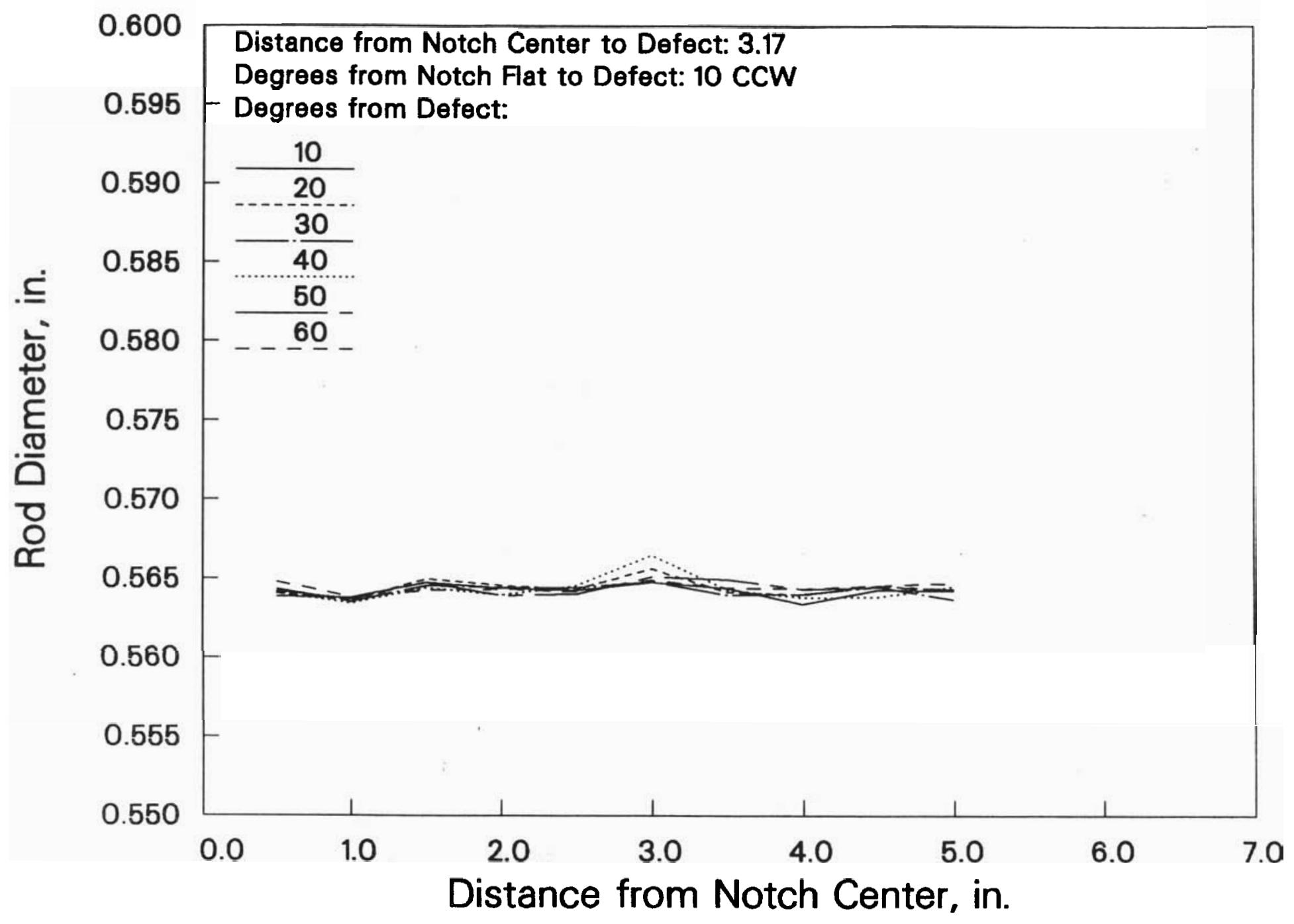

FIGURE 13. Typical Fuel-Rod Segment Diameter Profile Data 


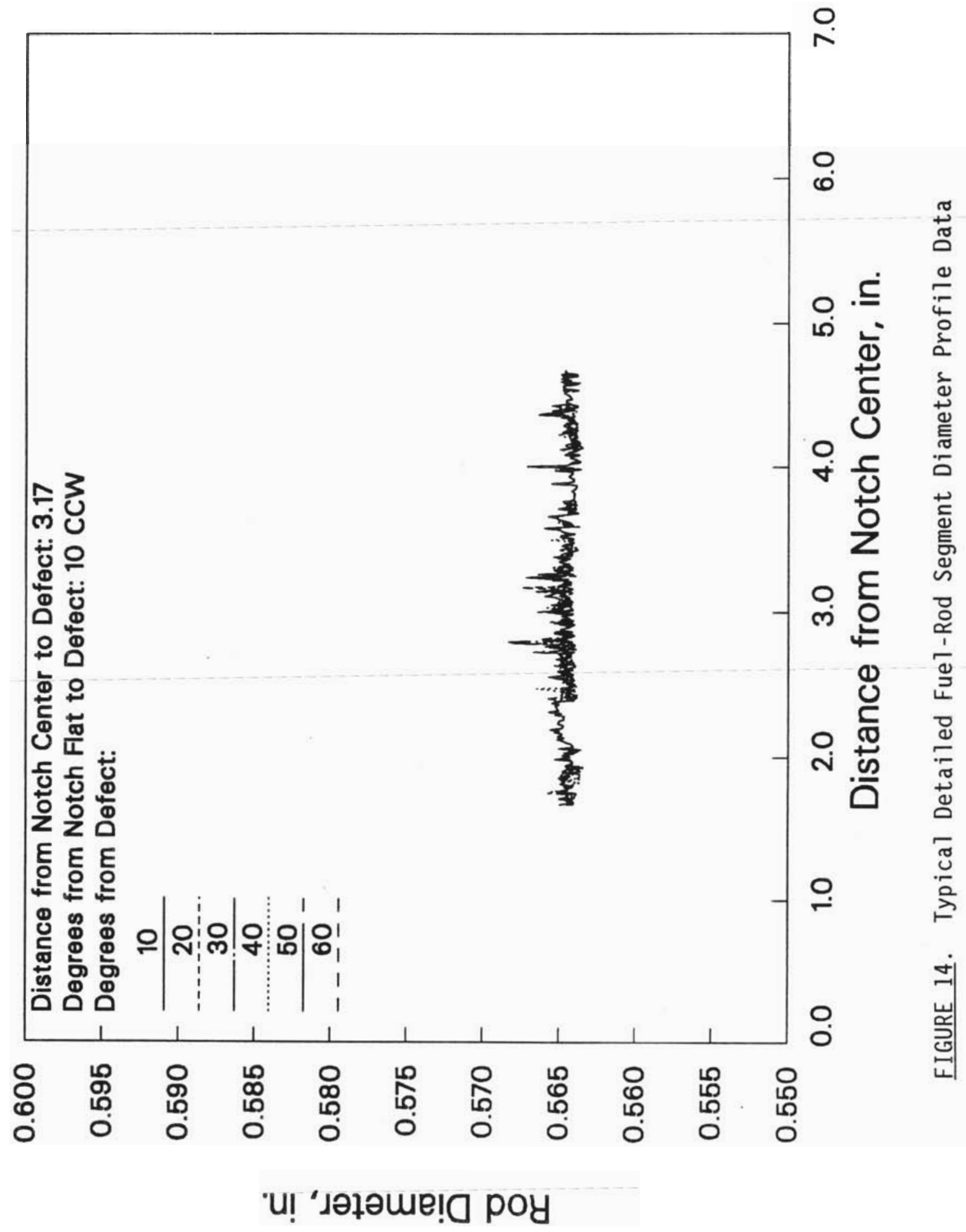


segments (33) during each interim examination was required. Detailed observations of powder formation and/or cladding strain and cracking through the 4-ft leaded-glass hot-ce11 windows were not possible without an enhanced viewing system. Photographs taken with the system provided a visual record of the physical effect of the oxidation reaction on the specimens. In particular, it enabled researchers to observe the formation of the fine $\mathrm{U}_{3} \mathrm{O}_{8}$ powder. The periscope allowed researchers to take instant and $35 \mathrm{~mm}-\mathrm{col}$ or or black-and-white photographs at magnifications of $2 X$ and $4 X$. Figure 15 contains typical photographs of a spent-fuel-fragment specimen taken in this facility with this equipment. 

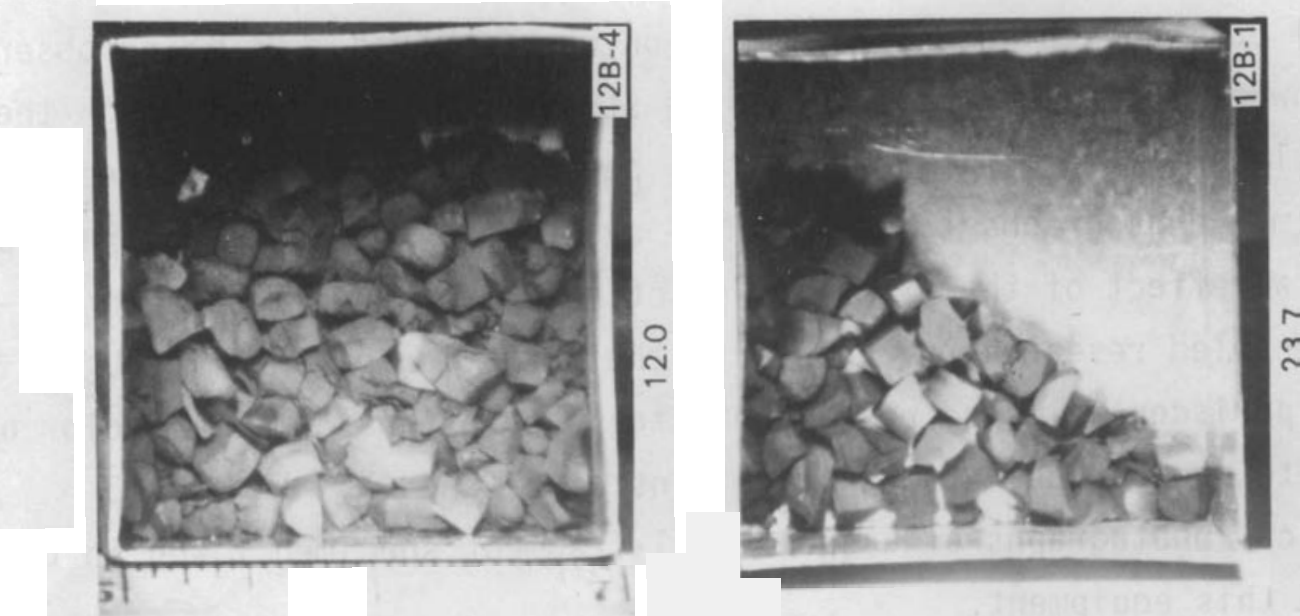

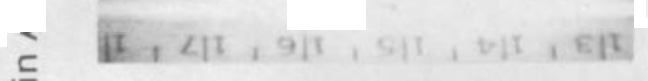
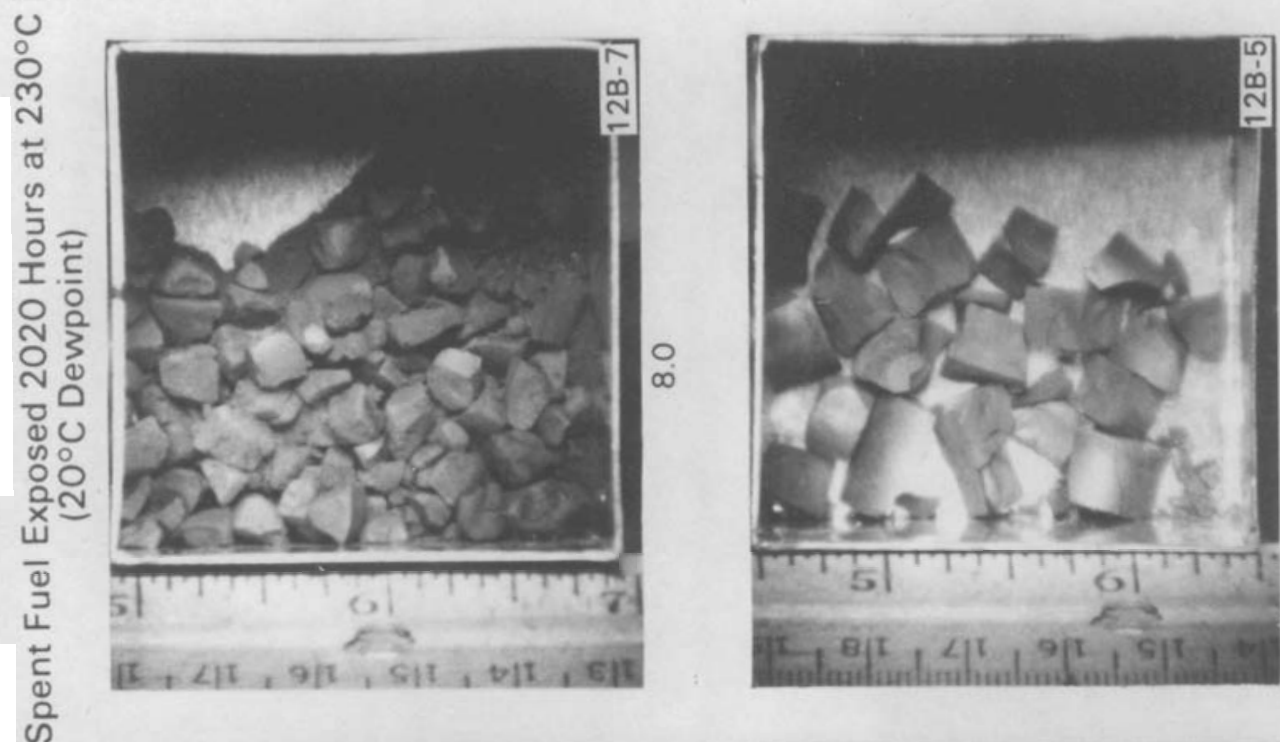

iู

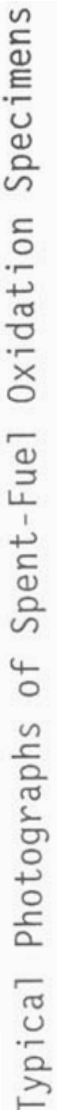
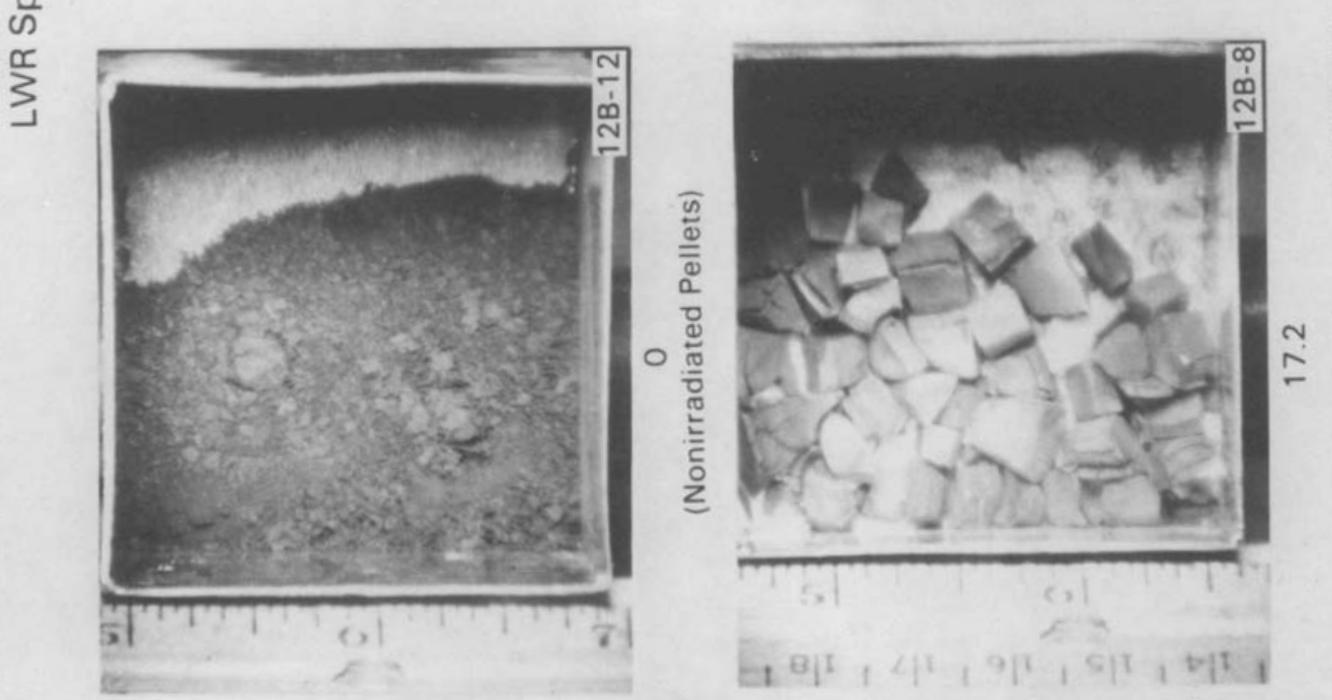

노 


\section{EXPERIMENTAL PROCEDURE AND RESULTS}

The oxidation behavior of spent- $\mathrm{UO}_{2}$ from different sources needed to be tested for this program. To satisfy that requirement, fuels from five different reactors were acquired, as shown in Table 2. The fuels were acquired as intact rods from Shippingport, Quad Cities, and Monticello, or as partial segments of a full-length rod from HB Robinson and Point Beach. A cutting diagram as shown in Figure 16 was prepared for each fuel rod or rod-segment. Samples were selected from designated fuel-rod locations prior to cutting to provide a range of burnup and fuel type for each oven. To provide a statistical estimate of within-oven variability, replicate samples were placed in the oven when possible.

TABLE 2. Spent Fuel Oxidation Test Specimen Fuel Sources Source Reactor Identification Fuel Type Size GWd/MTU(a)

Shippingport

Point Beach

HB Robinson

Quad Cities - 1
PWR

PWR

PWR

$$
\begin{aligned}
& 1 A 01-1 \\
& 1 A 01-2 \\
& 1 A 03-3 \\
& 1 B 02-4 \\
& 1 C 02-1 \\
& 1 C 02-4 \\
& \text { DTA010 }
\end{aligned}
$$

Monticello

$\begin{array}{lll}\text { OA03-4 } & \text { BWR } & 28.7(\mathrm{c}) \\ \text { OA08-4 } & \text { BWR } & 28.7(\mathrm{c}) \\ 5 \mathrm{D} 18-3 & \text { BWR } & 28.7(\mathrm{c})\end{array}$

(a) Average burnup of rod or rod segment unless otherwise noted.

(b) Estimated average burnup based on power history.

(c) Gamma scan used to determine burnups of samples assumed a linear relation between cesium-137 counts and burnup (Barner 1985; Guenther et a1. 1988). 


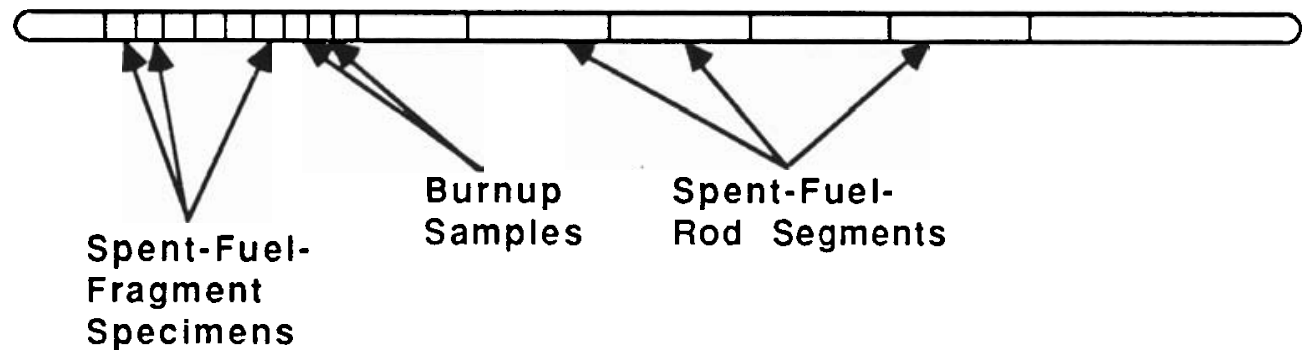

FIGURE 16. Typical Rod Cutting Diagram

\section{IESTING OF FRAGMENTS}

The spent-fuel-fragment specimens were prepared from $3.8-$ to $4.4-\mathrm{cm}$ long (1.5- to 1.75-in.) sections cut from the fuel rod. The fuel was removed from the cladding to obtain -25 to 40 grams of fragment specimen for testing. The fragment specimens were sieved (to remove fines less than No. 16 Tyler mesh screen) and $\mathrm{placed}$ in labeled aluminum specimen boats that had been previously weighed. Each specimen was weighed to obtain the starting weight.

Specimen boats containing the fragment specimens were carefully placed into oven shelf bins. The shelf-bin position of each sample was invariant throughout the course of the tests. The oven door was then sealed, and the oven was evacuated to $\sim 1 \mathrm{in} .(3.4 \mathrm{kPa}) \mathrm{Hp}$ absolute pressure to purge any possible moisture from its interior and to check the seal integrity. After evacuation, the inlet header valve to the oven was opened and the cap screw was loosened to allow gas to flow through the oven. Cover gas with the specified dew point flowed through until a minimum of three oven-volume exchanges had occurred; then the inlet header valve was closed and the cap screw was tightened.

While the oven was heated to the specified testing temperature, the cover gas was vented periodically through the pressure relief valve and cap screw fitting to prevent overpressurization and gasket blowout. Final oven pressure at test temperature was approximately 32- to 33-in. (109- to $112-\mathrm{kPa}) \mathrm{Hg}$ absolute pressure. The temperature of each oven shelf and oven pressure were recorded about every 1 to 2 days.

The period of time that an oven was at test temperature before shutdown of an oven "run" for an interim weighing was dependent on the temperature, 
with the higher temperature ovens being shut down more frequently, particularly during the early stages of the test. Prior to oven shutdown a cover gas sample was taken. After the samples cooled, specimen boats containing the fragments were carefully removed from the oven shelves and weighed twice to within $\pm 0.001 \mathrm{~g}( \pm 0.01 \mathrm{~g}$ if total weight was $60 \mathrm{~g}$ or higher). Spent-fuel-fragment specimens were visually examined for the presence of powders, degradation (e.g., crack formation, or a decrease in the size), and color change. Polaroid photographs were taken and the specimens were returned to the oven.

\section{IESTING OF SEGMENTS}

The rod segments were typically 14.0 - to $16.5-\mathrm{cm}(5.5-$ to $6.5-\mathrm{in}$.$) long$ and were prepared for welding by removing $-1.3 \mathrm{~cm}(0.5 \mathrm{in.})$ of the crud/oxide layer on the outer cladding. Approximately $1.3 \mathrm{~cm}(0.5 \mathrm{in.})$ of fuel fragments were removed from each end. The inner walls of the cladding were wiped with a cotton swab. A stainless steel cylindrical insert, $1.3-\mathrm{cm}$ $(0.5-i n$.$) long, was placed into the space created by the fuel removal. It$ was gently tapped with a hammer until the outside face was flush with the end of the cladding, and an endcap (inscribed with the rod segment identification) was $p l a c e d$ over the prepared end of the cladding. The entire assembly was then placed into the rotary-head tungsten inert-gas (TIG) welder. Welding parameters were set, the chamber was flooded with a $93 \%-7 \%$ argon-helium mix, and one endcap was welded to the cladding. This welding procedure was repeated for the other endcaps. Immediately following completion of the second weld, the rod segment was helium leak checked by placing the rod segment into a sealed cylindrical chamber and evacuating the airspace. A mass spectrometer, connected to the chamber through the hot-cell wall, detected any possible helium leaks at the welds. A leak rate below $1 \mathrm{x}$ $10^{-8} \mathrm{~cm}^{3} / \mathrm{s}$ was the acceptance criteria.

Next a $0.76-\mathrm{mm}(0.030-\mathrm{in}$.$) dia hole was drilled into the center of the$ rod segment by using the drill press. Following drilling, visual verification of the drilled hole was made using a hot cell periscope. A hole that 
had not penetrated the cladding had a bright reflective surface at the bottom of the drill site. This was not observed for a hole that had penetrated the cladding completely.

Following preparation, rod segments were photographed and weighed twice to the nearest $0.01 \mathrm{~g}$. Two pretest profilometry scans were made with the laser micrometer. One profile used a step size of $1.3 \mathrm{~cm}(0.5$ in.) and was made at 10 to 11 axial locations to characterize the entire rod length. A second scan at $0.025-$ or $0.050-\mathrm{cm}(0.01-$ or $0.02-$ in. $)$ spacing characterized the region within $3.8 \mathrm{~cm}(1.5 \mathrm{in.})$ of each side of the drilled hole.

Because of the length of time required to prepare the rod segments, they were added to the ovens after several thousand hours had accumulated on the spent-fuel-fragment specimens. During each subsequent interim examination, rod segments were also weighed twice (to $\pm 0.01 \mathrm{~g}$ ), examined, and photographed. In addition, two profilometry scans of the rod segments were made: 1) a full segment scan at $1.3-\mathrm{cm}$ spacing and 10 to 11 axial location and 2) a detailed scan covering a region centered at the site of the drilled hole.

After an interim examination, the oven gasket was replaced, the samples were returned to their shelf positions, the oven door sealed, and the oven was restarted as previously described.

\section{OPERATIONAL RESULTS}

The oven system and the atmosphere control system have been in operation since 1985 without any equipment failures (scoping tests were completed in this facility). The original controllers, however, were replaced as they did not provide adequate control to prevent significant temperature fluctuations. During the course of the oxidation tests, problems associated with moisture saturation of the gas lines in the atmosphere control system have occasionally occurred. This has resulted in dew points that are significantly greater than $40^{\circ} \mathrm{C}$. This problem is resolved by flowing dry air through the lines until the moisture is removed.

The welding and drilling systems were used to produce 33 spent-fuel-rod segments with artificially induced breaches. A significant effort was required to develop end caps and define welding parameters which produced 


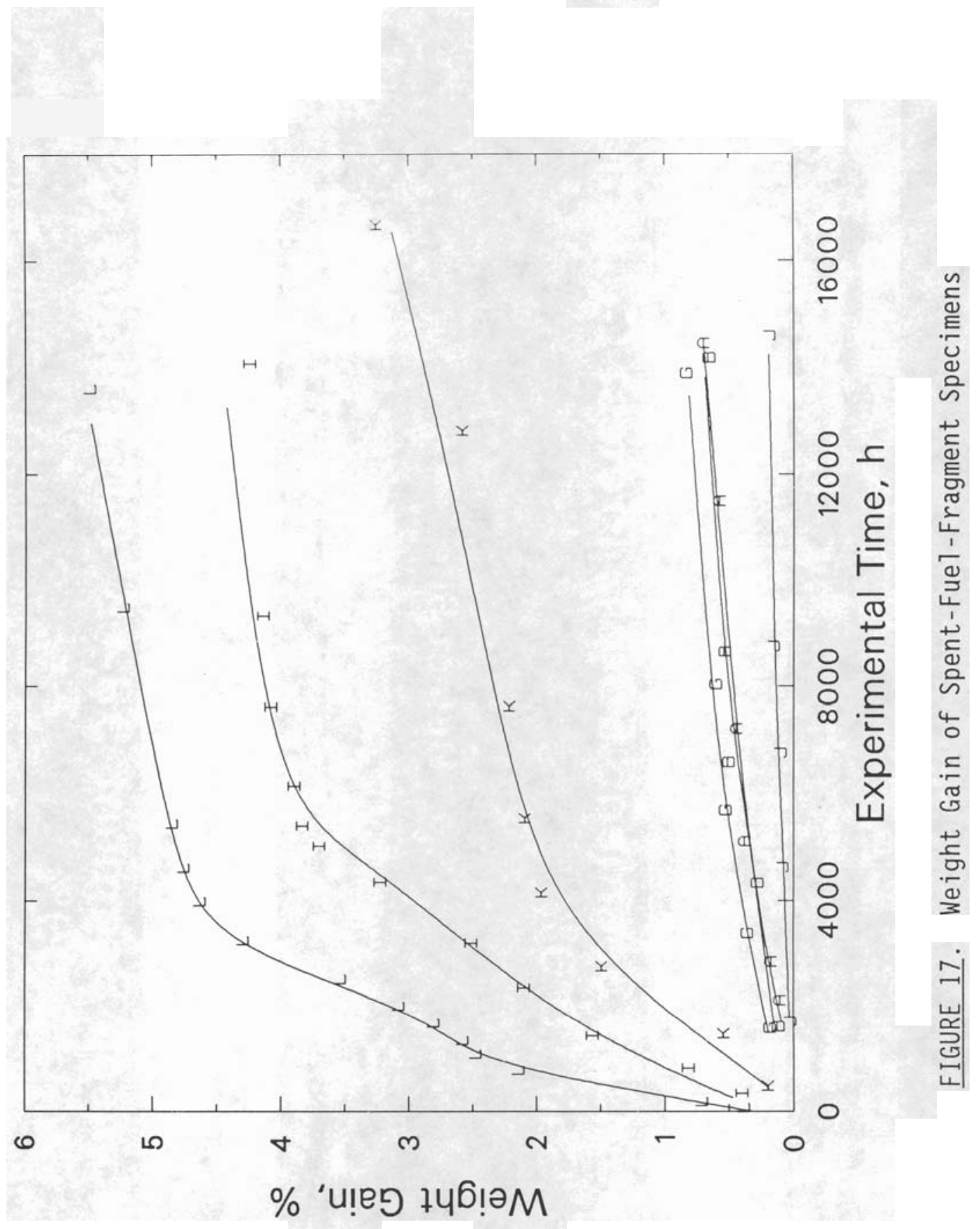




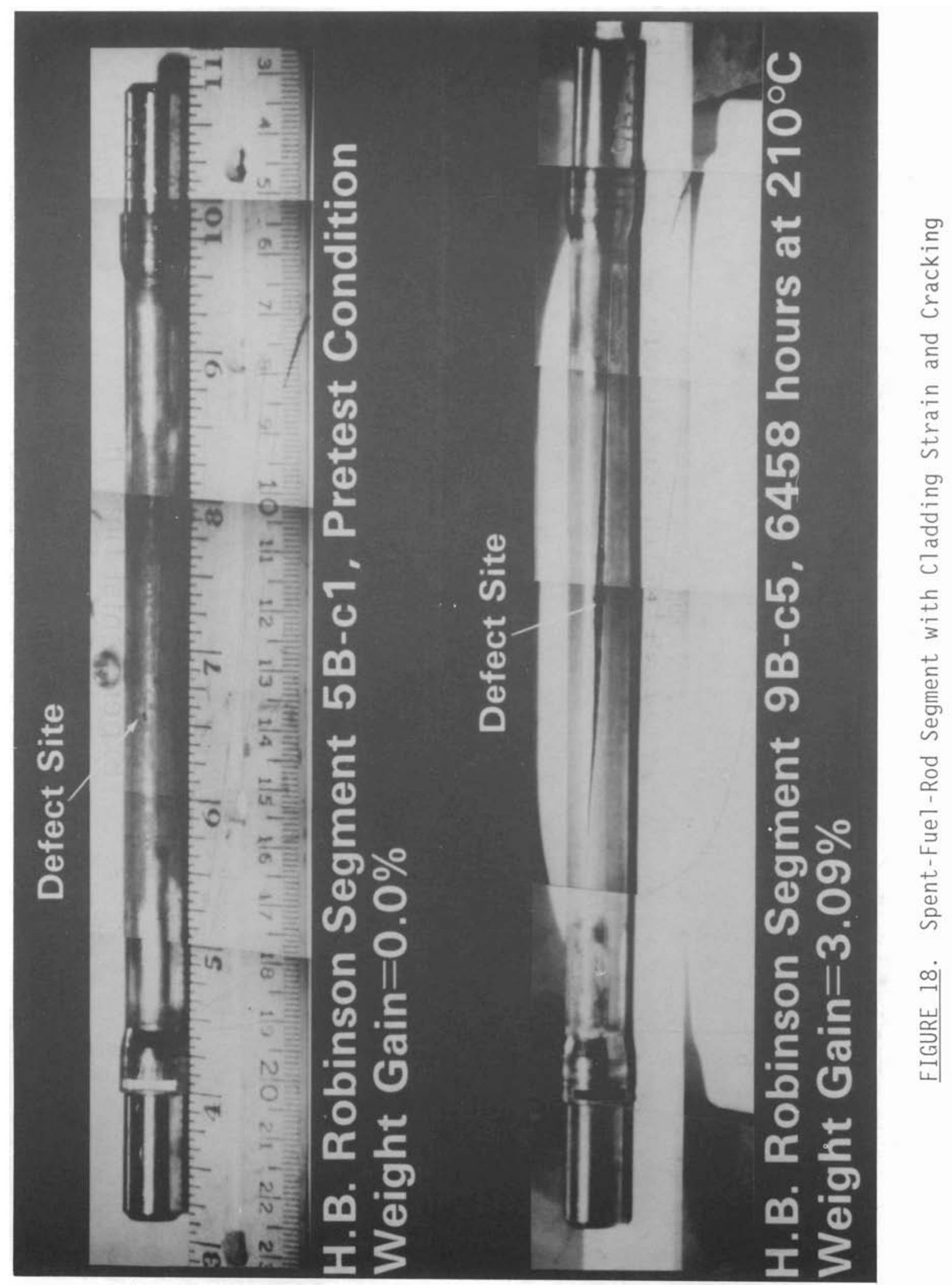


high-quality welds on the irradiated zircaloy cladding. Some difficulties were experienced with weld blow out during cold testing, but the addition of the stainless steel plugs resolved that problem. No weld blowouts occurred during actual segment welding. The drilling system met the requirements and completely penetrating the cladding with a 0.03-in.-dia defect. Drill bit breakage was a common occurrence which made this process quite time consuming, but each of the segments was successfully drilled.

The laser scanning component of the laser micrometer has required replacement. Despite the lead shielding, this unit appears to be susceptible to radiation damage--presumably from the rod segments themselves. It is time consuming to make this replacement. As a result, a decision was made to use a mechanical micrometer to make diameter measurements when the laser micrometer is not functioning. These readings are accurate to \pm .001 in., which is the practical limit of the laser unit.

For the spent-fuel-fragment specimens, the weight gain (oxidation) as a function of time for fuel from different sources over a range of temperatures was being measured. This data is summarized as it became available on data plots similar to the one shown in Figure 17. Details of this data have been published elsewhere (Campbel1 1987) and final documentation will be made when the tests have been terminated.

Similar weight gain data has been generated for the spent-fuel-rod segments. The segments were also monitored for cladding strain and cracking (Figure 18). Thus data on cladding strain as a function of time for fuel from different sources over a range of temperatures was measured. 


\section{CONCLUSIONS}

The spent-fuel-fragment oxidation tests were initiated between December 1985 and March 1986 at $135^{\circ}, 150^{\circ}, 170^{\circ}, 190^{\circ}, 210^{\circ}$ and $230^{\circ} \mathrm{C}$ with atmospheric dewpoints of $0^{\circ} \mathrm{C},+20^{\circ} \mathrm{C}$ and $+40^{\circ} \mathrm{C}$. Spent fuel from five different sources was tested. As of December 1988, the equipment has satisfactorily met the requirements originally established for each of the systems. The accomplishments include the following:

long-term, reliable ( $\pm 4^{\circ} \mathrm{C}$ of specified temperatures) operation of twelve ovens in a high-gamma radiation field control and measurement of the initial cover-gas composition in each oven and measurement of the final cover-gas composition development of procedures and hardware that permitted the production of high-quality end welds to irradiated zircaloy cladding drilling of $0.08-\mathrm{cm}(0.030 \mathrm{in.})$ defects in irradiated zircaloy cladding that penetrated the full thickness of cladding wall

- accurate measurements of cladding strain with a laser micrometer or mechanical micrometer

- observations and photographs of physical changes in fragment specimens and segments which occurred as a result of oxidation.

The data produced in this test facility are providing the primary data for the data base needed to determine acceptable temperature limits for dry air storage. 


\section{REFERENCES}

Barner, J. 0. 1985. Characterization of LWR Spent Fuel MCC-Approved Testing Material--ATM-101. PNL-5109, Rev. 1, Pacific Northwest Laboratory, Richland, Washington.

Belle, J. 1961. "Uranium Dioxide, Properties and Nuclear Applications," U.S. Government Printing Office, Washington, D.C.

Campbe11, T. K., E. R. Gilbert, C. K. Thornhi11, G. D. White, G. F. Piepel, and C.W. Griffin. 1987. Interim Results from U0 2 Fuel Oxidation Tests in Air. PNL-6201, Pacific Northwest Laboratory, RichTand, Washington.

Cunningham, M. E., E. P. Simonen, R. T. Alleman, I. S.Levy, R. F. Hazelton, and E. R. Gilbert. 1987. Control of Degradation of Spent Fuel During Dry Storage in an Inert Atmosphere. PNL-6364, Pacific Northwest Laboratory, Richland, Washington.

Einziger, R. E. 1983. "First Interim Examination of Whole Rod Tests at $230^{\circ} \mathrm{C}$." In Proceedings of the U.S. Nuclear Regulatory Commission Workshop on Spent Fuel/Cladding Reaction During Dry Storage. NUREG/CP0049, pg 45-69, U.S. Nuclear Regulatory Commission, Gaithersburg, Maryland.

Guenther, R. J., D. E. Blahnik, T. K. Campbel1, U. P. Jenquin, J. E. Mendel, L. E. Thomas, and C. K. Thornhill. 1988. Characterization of Spent Fuel Approved Testing Material--ATM-103. PNL-5109-103, Pacific Northwest Laboratory, Richland, Washington.

White, G. D., C. A. Knox, E. R. Gilbert and A. B. Johnson, Jr. 1983. "Oxidation of $\mathrm{UO}_{2}$ at $150-350^{\circ} \mathrm{C}$." In Proceedings of the U.S. Nuclear Regulatory Commission Workshop on Spent Fuel/Cladding Reaction During Dry Storage. NUREG/CP0049, pp. 102-110, U.S. Nuclear Regulatory Commission, Gaithersburg, Maryland. 


\section{DISTRIBUTION}

No. of

Copies

\section{OFFSITE}

10 DOE/Office of Scientific and Technical Information

R. Stein

Office of Civilian Radioactive Waste Management

U.S. Department of Energy

RW-30

Washington, DC 20585

T. Nguyen

Office of Civilian Radioactive Waste Management

U.S. Department of Energy

$\mathrm{RW}-32$

Washington, DC 20585

W. Danker

Office of Civilian Radioactive Waste Management

U.S. Department of Energy

$\mathrm{RW}-33$

Washington, DC 20585

K. A. Klein

Office of Civilian Radioactive Waste Management

U.S. Department of Energy

RW-32

Washington, DC 20545

C. Head

Office of Civilian Radioactive Waste Management

U.S. Department of Energy

RW-32

Washington, DC 20545

J. S. Finucane

Energy Information Administration

U.S. Department of Energy

EI-53

Washington, DC 20545
No. of

Copies
K. G. Golliher

U.S. Department of Energy

Albuquerque Operations Office P.0. Box 5400

Albuquerque, NM 87115

S. Mann

U.S. Department of Energy

Chicago Operations Office

Argonne, IL 60439

M. Fisher

U.S. Department of Energy

Idaho Operations Office

785 DOE Place

Idaho Falls, ID 83402

S. T. Hinschberger

U.S. Department of Energy

Idaho Operations office

785 DOE Place

Idaho Falls, ID 83402

C. Matthews

U.S. Department of Energy

Oak Ridge Operations Office

P.0. Box E

Oak Ridge, TN 37830

C. J. Dankowski

U.S. Department of Energy Defense Programs

San Francisco Operations Office

1333 Broadway

Oakland, CA 94612

C. P. Gertz

U.S. Department of Energy Waste Management Project Office P.0. Box 98518

Las Vegas, NV 89193-8518 
No. of

Copies

10

J. Carter
National Energy Software
Center

Argonne National Laboratory

9700 South Cass Avenue

Argonne, IL 60439

B. A. Chin

Auburn University

Mechanical Engineering Dept.

247 Wilmore Laboratories

Auburn, AL 36830

P. Childress

Babcock \& Wilcox Co.

P.0. Box 10935

Lynchburg, VA 24506-0935

L. A. Walton

Babcock \& Wilcox Co.

P.0. Box 10935

Lynchburg, VA 24506-0935

P. A. File

Baltimore Gas and Electric Co.

Calvert Cliffs Nuclear Power Plant

Lusby, MO 20657

R. Kohli

Battelle, Columbus Division

505 King Avenue

Columbus, OH 43201

V. Pasupathi

Battelle, Columbus Division

505 King Avenue

Columbus, $\mathrm{OH} 43201$

5 T. W. Wood

Battelle, Pacific Northwest Laboratories

370 L'Enfant Promenade SW

Washington, DC 20024-2115

G. H. Beeman

Battelle, Pacific Northwest Laboratories

370 L'Enfant Promenade SW

Washington, DC 20024-2115
No. of

Copies

J. A. Carr

Battelle, Project Management Division

Office of Nuclear Waste Isolation

505 King Avenue

Columbus, $\mathrm{OH} 43201$

G. A. Townes

$B E$ Inc.

P.0. Box 145

New Ellenton, SC 29809

L. J. Jardine

Bechtel National Inc.

P.0. Box 3965

San Francisco, CA 94119

G. E. Lucas

University of California

Dept. of Chemical and Nuclear Engineering

Santa Barbara, CA 93106

D. R. 01 ander

University of California

647 San Fernando Avenue

Berkeley, CA 94707

R. Kunita

Carolina Power \& Light Co.

411 Fayetteville St.

P.0. Box 1551

Raleigh, NC 27602

L. Martin

Carolina Power \& Light Co.

411 Fayetteville St.

P.0. Box 1551

Raleigh, NC 27602

G. C. Jobson

Chem-Nuclear Systems, Inc.

One Greystone West Building

240 Stoneridge Drive, Suite 100

Columbia, SC 29210 
No. of

Copies

C. K. Anderson

Combustion Engineering, Inc. 1000 Prospect Hill Road

Windsor, CT 06095

N. Fuhrman

Combustion Engineering, Inc. 1000 Prospect Hill Road

Windsor, CT 06095

G. P. Wagner

Commonwealth Edison

Nuclear Stations Division

P.0. Box 767

Chicago, IL 60690

T. J. Marz

Consumers Power Company

1945 W. Parnal1 Road

Jackson, MI 49201

S. J. Raffety

Dairyland Power Coop.

2615 E. Ave. S.

LaCrosse, WI 54601

R. W. Rasmussen

Duke Power Company

P.0. Box 33189

Charlotte, NC 28242

Ebasco Services, Inc.

Two World Trade Center

New York, NY 10098

R. Stanford

Edison Electric Institute

1111 19th St. NW

Washington, DC 20036

R. Maughan

EG\&G Idaho, Inc.

P.0. Box 1625

Idaho Falls, ID 83415

R. W. Lambert

Electric Power Research Institute

P.0. Box 10412

Palo Alto, CA 94304
No. of

Copies

R. F. Williams

Electric Power Research Institute

P.0. Box 10412

Palo Alto, CA 94304

G. T. Zamry

Florida Power \& Light Co. 9250 W. Flagler St.

Miami, FL 33174

FLUOR Engineers, Inc.

Advanced Technology Division

P.0. Box C-11944

Santa Ana, CA 92711-1944

B. K. Agarwal

FW Energy Applications, Inc.

110 Orange Avenue

Livingston, NJ 07039

E. Engles

General Electric Co.

Morris Operation

Morris, IL 60450

W. L. Dobson

Gilbert Associates, Inc.

P.0. Box 1498

Reading, PA 19603

V. J. Barnhart

GNSI

135 Darling Dr.

Avon, CT 06001

B. Handly

Houston Lighting \& Power Co.

Nuclear Fuels-SPII

12301 Kurland Dr.

Houston, TX 77034

E. R. Johnson

E. R. Johnson Associates, Inc. 11702 Bowman Green Drive

Reston, VA 22090

J. A. McBride

E. R. Johnson Associates, Inc.

11702 Bowman Green Drive

Reston, VA 22090 
No. of

Copies

L. M. Trosten

LeBoeuf, Lamb, Leiby, \& MacRae 1333 New Hampshire Ave. NW

Washington, DC 20036

L. B. Ballou

Lawrence Livermore National

Laboratory

P.0. Box 808

Livermore, CA 94550

L. D. Ramspott

Lawrence Livermore National Laboratory

P.0. Box 808

MS L404

Livermore, CA 94550

M. Schwartz

Lawrence Livermore National Laboratory

P.0. Box 808 - MS L197

Livermore, CA 94550

C. F. Smith

Lawrence Livermore National Laboratory

P.0. Box 808

Livermore, CA 94550

J. H. Garrity

Maine Yankee Atomic Power Co.

Edison Drive

August, ME 04336

G. D. Whittier

Maine Yankee Atomic Power Co.

Edison Drive

August, ME 04336

R. Whale

Michigan Public Service

Commission

6545 Mercantile Way

Lansing, MI 48909

M. Kupinski

Northeast Utilities Service Co.

P.0. Box 270

Hartford, CT 06101
No. of

Copies

H. Shaw

Lawrence Livermore National

Laboratory

Waste Package Task, NNWSI

P.0. Box 808 - MS L206

Livermore, CA 94550

J. Houston

Nuclear Assurance Corp.

5720 Peachtree Parkway

Norcross, GA 30092

C. B. Woodhall

Nuclear Assurance Corp.

5720 Peachtree Parkway

Norcross, GA 30092

J. Clark

Nuclear Fuel Services

6000 Executive Blvd.

Rockville, MD 20852

B. Lehnert

NUTECH Engineers

145 Martinvale Lane

San Jose, CA 95119

G. J. Antonucci

NUS Corporation

910 Clopper Rd.

Gaithersburg, MD 20878

J. V. Massey

Reedy \& Associates

15951 Los Gatos Blvd., Suite 1

Los Gatos, CA 95032

J. Van Cleve

Oak Ridge National Laboratory

P.0. Box $X$

Oak Ridge, TN 37831

M. Litterman

Portland General Electric, Trojan Fuel

121 SW Salmon St.

Portland, OR 97204 
No. of

Copies

D. Woods

Ralph M. Parsons Co.

700 West Walnut Street

Pasadena, CA 91124

A. A. Fuierer

Rochester Gas and Electric Corporation

89 East Avenue

Rochester, NY 14649-0001

G. C. Allen

Sandia National Laboratory

Division 6323

Transportation Technology Center P.0. Box 5800

Albuquerque, NM 87185

J. F. Ney

Sandia National Laboratory

Division 6323

Transportation Technology Center

P.0. Box 5800

Albuquerque, NM 87185

T. L. Sanders

Sandia National Laboratory

P.0. Box 5800

Albuquerque, NM 87185

E. Kuhns

Stone and Webster Engineering Corp.

1 Penn Plaza

250 w. 34th St.

New York, NY 10119

E. Gordon

Transnuclear, Inc.

507 Newmark Esplanade

Rockville, MD 20850

J. Mangusi

Transnuclear, Inc.

1 N. Broadway

White Plains, NY 10601

B. R. Teer

Transnuclear, Inc.

1 N. Broadway

White Plains, NY 10601
No. of

Copies

TRW, Exploration/Pro

P.0. Box 441807

Houston, TX 77244-1807

M. Keyhani

University of Tennessee

College of Engineering

414 Dougherty Eng. Bldg.

Knoxville, TN 37996-2210

R. J. Mullin

Tennessee Valley Authority

1101 Market St.

BR6N Space 40A

Chattanooga, TN 37402

F. C. Sturz

U.S. Nuclear Regulatory Commission

Office of Nuclear Materials

Safety and Safeguards

Washington, DC 20555

C. Feldman

U.S. Nuclear Regulatory Commission

Office of Nuclear Materials Safety and Safeguards Washington, DC 20555

W. R. Pearson

U.S. Nuclear Regulatory Commission

Regulatory Applications Division MS NL-007

Washington, DC 20555

C. H. Peterson

U.S. Nuclear Regulatory

Commission

Office of Nuclear Materials

Safety and Safeguards

MS 623-SS

Washington, DC 20555 
No. of

Copies

J. Roberts

U.S. Nuclear Regulatory Commission

Office of Nuclear Materials Safety and Safeguards

Washington, DC 20555

L. C. Rouse

U.S. Nuclear Regulatory Commission

Division of Fuel Cycle

Material Safety

Washington, DC 20555

S. P. Turel

U.S. Nuclear Regulatory Commission

Office of Nuclear Materials Safety and Safeguards

Washington, DC 20555

P. K. Shaver

U.S. Tool and Die, Inc. 4030 Route 8

Allison Park, PA 15101

W. J. Wachter

U.S. Tool and Die, Inc.

1465 Glenn Avenue

Glenshaw, PA 15116

J. A. Nevshemal

Toledo Edison Co.

2155 Kathy Lane

Genoa, $\mathrm{OH} 43430$

E. A. Bassler

Westinghouse Electric Corp. P.0. Box 2728

Pittsburgh, PA 15230

C. F. Davis

Westinghouse Electric Corp. Waste Technology Services Div.

P.0. Box 10864

Pittsburgh, PA 15236

P. S. Klanian

Westinghouse Electric Corp.

c/o West Valley Nuclear Services

P.0. Box 191

West Valley, NY 14171
No. of

Copies

E. Benz

R. F. Weston Co.

955 L Enfant Plaza SW

8th Floor

Washington, DC 20024-2119

N. Dayem

R. F. Weston Co.

955 L Enfant Plaza SW

8th Floor

Washington, DC 20024-2119

\section{ONSITE}

2 DOE Richland Operations Office

D. E. Kenyon

E. C. Norman

1 Westinghouse Hanford Company

C. L. Brown

61 Pacific Northwest Laboratory

M. J. Apted

W. J. Bailey

J. 0. Barner

C. E. Beyer

D. J. Bradley

H. C. Burkholder

T. K. Campbell (3)

T. D. Chikalla

J. M. Creer (5)

M. E. Cunningham

P. G. Doctor

R. E. Einziger

M. D. Freshley

E. R. Gilbert (5)

R. J. Guenther

R. F. Hazelton

C. M. Heeb

R. E. Heineman

A. B. Johnson, Jr.

R. W. Knoll

M. R. Kreiter

D. D. Lanning

S. C. Marschman

J. L. McElroy 
No. of

Copies

M. A. McKinnon

J.T.A. Roberts

D. J. Silviera

E. P. Simonen

0. D. Slagle

H. D. Smith

R. I. Smith

J. L. Straalslund

L. A. Strope

C. K. Thornhill (5)

R. E. Thornhill (5)

R. C. Walling

C. N. Hilson

Publishing Coordination

Technical Report Files (5) 